\title{
Abstracts of Papers Presented at the General Scientific Meetings of the Marine Biological Laboratory August 14-16, 1989
}

\begin{abstract}
s are arranged alphabetically by first author within the following categories: cell motility and cytoskeleton; gametes and developmental biology; general physiology; neurobiology; pathobiology and environmental studies; and sensory biology. Author and subject references will be found in the regular volume index in the December issue.
\end{abstract}

\section{Cell Motility and Cytoskeleton}

\section{Calcium-sensitive ATP-reactivated models of Ciona in-} testinalis branchial basket cilia. DWIGHT E. BERGLES AND Sidney L. TAMm (Boston University Marine Program).

The cilia lining the stigmata of the branchial basket of Ciona intestinalis generate the water currents necessary for feeding and gas exchange. The metachronal beating of these cilia is often interrupted by sudden stigmata-wide arrests, in which the cilia lie flat against the stigmatal opening. These arrests are always followed by a transient inactive state in which the cilia rise to an upright position before metachronal beating resumes (Takahashi et al. 1973, J. Fac. Sci. U. Tokyo 13: 123137). To investigate the ionic and molecular control of these motor responses, we have developed permeabilized ATP-reactivated models of Ciona cilia.

Cell models were produced by extracting small pieces of branchial basket in $0.1 \%$ saponin, $10 \mathrm{~m} M$ EGTA, $30 \mathrm{~m} M$ PIPES, $150 \mathrm{mM} \mathrm{KCl}$, $10 \mathrm{mM} \mathrm{MgCl}$, pH 7 (ES) for 4-7 min at room temperature. TEM showed that this treatment disrupted or completely removed the ciliary membranes. Transfer of extracted tissue to reactivation solution (RS: $10 \mathrm{~m} M$ EGTA, $30 \mathrm{~m} M$ PIPES, $150 \mathrm{mM} \mathrm{KCl}, 10 \mathrm{~m} M \mathrm{MgCl}_{2}, 2 \mathrm{~m} M$ ATP, $1 \mathrm{~m} M$ DTT, pH 8.0) caused the cilia to beat rapidly and without metachrony for 15-30 min.

Calcium $(20 \mu M-1 \mathrm{~m} M)$ in EGTA-free RS induces the cilia to assume an inactivated posture (stigmata closed), but not the arrested state (stigmata open). Calcium-dependent inactivation is reversed, and the cilia resume beating in the presence of $100 \mu M$ trifluoperazine (TFP) or calmidazolium, indicating that ciliary inactivation is regulated by a calcium-calmodulin pathway. The absence of a full laydown arrest in our ciliary models may be due to a loss or modification of critical control factors during extraction. Preliminary results using cAMP, phosphatases, and phosphatase inhibitors suggest that ciliary responses are mediated by protein phosphorylation levels.

Supported by NIH Grant GM 27903 to S.L.T.
Studies of membrane and cytoskeletal structures by electroporation using a radio-frequency electric field. DONALD C. CHANG AND QIANG ZHENG (Baylor College of Medicine, Houston, TX 77030).

High intensity pulsed electric fields can be used to transiently permeabilize cell membranes. This method, called "electroporation," is employed to introduce exogenous molecules into cells. Recently, we developed a new method of electroporation, in which a radio-frequency (RF) electric field, rather than a direct current (DC) field, permeabilizes cells. This new method improves cell viability and provides higher poration efficiency. In the first part of this study, we used the RF poration method to introduce rhodamine-labelled phalloidin into an attached cell line $(\mathrm{CV}-1)$ in order to study the microfilament system within the living cell. The $\mathrm{CV}-1$ cells were grown on coverslips. In the presence of phalloidin, cells in the center region of the coverslip were exposed to pulses of RF electric field $(0.8 \mathrm{kV} / \mathrm{cm}, 100 \mathrm{kHz}, 1 \mathrm{~ms}$ wide). The cells were washed and then incubated in normal culture medium at $37^{\circ} \mathrm{C}$ for $30 \mathrm{~min}$ before being observed under a fluorescence microscope. Brilliant rhodamin-labelled stress fibers were found in nearly all cells exposed to the RF field, but none were found in the control cells. From morphological observations, we estimated that over $60 \%$ of the cells loaded with rhodamine were viable.

In the second study, we used a rapid-freezing electron microscopy technique to examine the change of membrane structure following the $\mathrm{RF}$ electroporation process. Human red blood cells were used in this study because their membranes had already been well characterized. Following the exposure to the electric field, volcano-shaped, pore-like structures were found in the membranes of the porated cells. Their openings were approximately $20 \mathrm{~nm}$ in diameter in the first few milliseconds after the pulsation. In the next $50 \mathrm{~ms}$, their openings expanded and some of them were as large as $120 \mathrm{~nm}$ in diameter. Such expansion suggests that the electropores were shaped, not only by the electrical breakdown of the membrane, but also by secondary effects involving movement of water, ions, and other molecules.

Supported in part by a grant from the Texas Advanced Technology Program.

Quantitative motion analysis of vesicle movement in $Y-1$ adrenocortical cells and the use of fluorescent probes to identify the organelles. GEORGE M. LANGFORD (University of North Carolina, Chapel Hill), SANDRA A. Murray, Brockton HefFlin, and KathleEn J. PENNY. 
Video microscopy was used to study the motion of vesicular organelles in Y-1 adrenocortical tumor cells. The organelle movements were recorded in real time and subjected to quantitative motion analysis. Y-1 cells form a typical epithelial monolayer in culture, with broad extensions of very shallow depth (1-2 $\mu \mathrm{m})$. In the extensions, vesicles can be observed moving away from (anterograde), toward (retrograde), and lateral to the nucleus. The movements observed are presumed to be microtubule-dependent, as has been shown for organelle movement in axons. When stimulated with dibutyryl cAMP $(1 \mathrm{mM})$ for 8-24 hours, these cells showed a 3-6 fold increase in steroid production. The motion of several organelles (lipid granules) in unstimulated cells were quantitatively analyzed. Their movement can be classified as interrupted motion II according to the preliminary scheme of Weiss et al. (1986, Cell Motil. Cytoskel. 6: 128). This classification refers to organelles that show pauses and reversals, and is typical of organelle movement in cultured cells. The instantaneous velocity ( 0.33 -s intervals) was determined for three lipid granules. The fastest moving organelle had a maximum velocity of $2.0 \mu \mathrm{m} / \mathrm{s}$. The velocities of the organelles fluctuated, and the average velocities for the three organelles ranged between 0.4 and $1.1 \mu \mathrm{m} / \mathrm{s}$. Each organelle showed periods of movement followed by pauses. During a pause, the organelle remained in place as though tethered to the microtubule and resumed moving at maximum rates as though a force was being constantly applied to free it from an obstacle in its path. Rhodamine 123 and DIOC6 were used to identify the mitochondria and endoplasmic reticulum in these cells. Future studies are designed to determine changes in the movement pattern upon stimulation with ACTH and dibutyryl cAMP.

Supported by NSF grants DCB 8818279 to G.M.L. and RII- 8402666 to S.A.M. B.H. was supported by a fellowship from the American Society for Cell Biology; K.J.P. was supported by a fellowship from the American Physiological Society.

\section{Paddle cilia occur as artifacts in veliger larvae of Spisula solidissima and Lyrodus pedicellatus. GRAHAM SHORT AND SIDNEY TAMM (Boston University Ma- rine Program).}

Cilia with paddle-shaped tips (paddle cilia or discocilia) have been described by TEM and SEM in a variety of marine invertebrates, most recently in the pretrochal ciliary bands of Spisula solidissima veligers (Campos et al. 1989, Biol. Bull. 175: 343-348). We have investigated whether such modified cilia are genuine structures or artifacts of osmolarity or fixation conditions.

Living veligers of Spisula were observed in normal seawater by highspeed video microscopy (DIC and phase-contrast) synchronized with a strobe flash. No paddle cilia were present. The SEM fixative of Campos et al. (1989), consisting of $2.5 \%$ gluteraldehyde, $0.1 \mathrm{M}$ Na cacodylate, $\mathrm{pH} 7.2$, has an osmolarity of 404 mosmol; it induced paddle cilia in our Spisula veligers, as determined by light microscopy and SEM. Addition of $0.29 \mathrm{M} \mathrm{NaCl}$ to this fixative ( $\mathrm{pH} 7.1$ ) to make it isosmotic with MBL seawater ( 920 mOsmols) produced no paddle cilia. Similarly, an isosmotic fixative ( $\mathrm{pH} \mathrm{6.3)} \mathrm{containing} 2.5 \%$ gluteraldehyde, $0.13 \mathrm{M} \mathrm{NaCl}$, and $50 \%$ seawater did not induce paddle cilia.

The same fixation conditions applied to shipworm larvae (Lyrodus pedicellatus) gave the same results as described in Spisula. When living Spisula and Lyrodus were placed in diluted seawater $(45 \% ; 420$ mOsmols), the distal ciliary membrane vesiculated, as determined by light microscopy. This hypotonic swelling is reversible; the cilia regain their normal appearance when the larvae are returned to $100 \%$ seawater.

We conclude that paddle cilia in Spisula larvae, and probably in other invertebrates as well, are artifacts caused by swelling of the distal ciliary membrane in hypotonic medium. Various hydromechanical and chemosensory functions attributed to paddle cilia by previous au- thors (Matera et al. 1982, Cell Tiss. Res. 222: 25-40; Stebbing et al. 1972, Mar Biol. Assoc. UK 52: 443-448) must therefore be abandoned.

Supported by the Woods Hole Marine Science Consortium and NIH Grant GM 27903 to S.L.T.

\section{Cell fusion induced by a radio-frequency electric field. QI- ANG ZHENG AND DONALD C. CHANG (Baylor College of Medicine, Houston, TX 77030).}

Cell fusion is a very important and useful technique for hybridoma production and somatic hybridization. High intensity pulsed electric fields can be used to induce cell fusion; this is called "electrofusion." Using a new method of electrofusion developed in this laboratory, we applied a radio-frequency (RF) electric field to induce fusion of plant protoplasts and mammalian cultured cells. In the first study, protoplasts enzymatically digested from cabbage leaves were fused using three pulses of an RF field $(1 \mathrm{kV} / \mathrm{cm}, 60 \mathrm{kHz}, 0.2 \mathrm{~ms})$. Within a few minutes after pulsation, over $70 \%$ of protoplasts fused, and microscopic observation showed very little damage to the protoplasts by the RF field. In the second study, attached mammalian cells (CV-1, COS-M6, Pam, 3T3) were fused by the RF method. We observed a high frequency of fusion in all of these cells. For example, the fusion frequency of attached CV-1 cells could reach $80 \%$ even when they were treated using a single RF pulse $(1.0 \mathrm{kV} / \mathrm{cm}, 100 \mathrm{kHz}, 0.2 \mathrm{~ms})$; in this case, almost all cells were alive. To understand the mechanisms of cell fusion, we investigated the role of the cytoskeleton in reorganizing the cellular structures during the fusion process. The cytoskeletal changes of attached CV-1 cells were examined by fluorescence microscopy using rhodamine-phalloidin and anti-tubulin antibodies labelled with FITC. Within a few minutes after the electric pulsation, the membranes fused. During the next $20-30 \mathrm{~min}$, some of the stress fibers gradually disappeared; $F$ actin began to condense near the nucleus or at the cell periphery, while microtubules condensed between nuclei within the fusing cells. If the fusion involved only 2 or 3 neighboring cells, the fusion process was almost completed after about $90 \mathrm{~min}$. Apparently normal stress fibers reappeared at this time.

Supported in part by Texas Advanced Technology Program.

\section{Gametes and Developmental Biology}

\section{Binding of 5-hydroxytryptamine to isolated plasma membranes of Spisula gametes. A. H. BANDIVDEKAR (The Population Council), S. J. SEgal, AND S. S. KOIDE.}

Serotonin (5-hydroxytryptamine, 5-HT) added in vitro to a suspension of Spisula oocytes induced germinal vesicle breakdown (GVBD). The neurotransmitter also stimulated, in vitro, the motility of cold-immobilized Spisula sperm. In the present study, the plasma membranes were prepared from Spisula oocytes and sperm, and the binding of $\left[{ }^{3} \mathrm{H}\right] 5-\mathrm{HT}$ to the membranes was determined. 5-HT analogs were used to displace the bound $\left[{ }^{3} \mathrm{H}\right] 5-\mathrm{HT}$ to determine the types of receptors present on oocytes and sperm membranes.

Plasma membranes of oocytes were prepared by suspending isolated washed Spisula oocytes in $50 \mathrm{mM}$ Tris- $\mathrm{HCl}$ buffer, $\mathrm{pH} 7.4$, containing $1 \mathrm{~m} M$ EDTA, $0.001 \%$ sodium azide. The membranes were homogenized with 2-4 light strokes in a glass-teflon homogenizer, and sedimented by centrifugation.

Spisula sperm membranes were prepared by a nitrogen cavitation method, at a pressure of 1500 psi for $30 \mathrm{~min}$. The treated sperm were then centrifuged at $10,000 \times g$ for $30 \mathrm{~min}$ at $4^{\circ} \mathrm{C}$, and the supernatant centrifuged at $100,000 \times g$ for $2 \mathrm{~h}$ at $4^{\circ} \mathrm{C}$ to sediment the membranes.

The radioligand binding assay system contained $100 \mu \mathrm{g}$ of membrane 
protein, and $100 \mu \mathrm{l}$ of $\left[{ }^{3} \mathrm{H}\right] 5-\mathrm{HT}$ (40 pmoles); labelled ligand was displaced with 5-HT and its analogs.

The Kd of $\left[{ }^{3} \mathrm{H}\right] 5-\mathrm{HT}$ binding to Spisula oocyte and sperm membranes was $17.5 \mathrm{n} M$ and $2.7 \mathrm{n} M$, respectively. The maximum binding capacity was $7.9 \mathrm{pmoles} / \mathrm{mg}$ and $11.25 \mathrm{pmoles} / \mathrm{mg}$, respectively. The order of decreasing potency in the displacement of $\left[{ }^{3} \mathrm{H}\right] 5-\mathrm{HT}$ binding to Spisula oocyte membranes by $5-\mathrm{HT}$ agonists was: $5-\mathrm{HT}>5-\mathrm{CT}>8$ OH-DPAT $>2$-methyl-5-HT > alpha-methyl-5-HT, and that by 5-HT antagonists was ICS-205-930 > mianserin > methysergide $>$ BMY$7378>$ ketanserin $>$ quipazine. The order of decreasing potency in the displacement of $\left[{ }^{3} \mathrm{H}\right] 5$-HT bound to sperm plasma membranes by 5 HT agonists was 2-methyl-5-HT $>8$-OH-DPAT $>5$-HT $>5$-CT $>$ alpha-methyl-5-HT, and that by antagonists was ICS-205-930 $>$ BMY-7378 $>$ mianserin $>$ methysergide.

The present findings demonstrate that plasma membranes of Spisula oocytes and sperm possess $5-\mathrm{HT}_{1 \mathrm{~A}}$ and $5-\mathrm{HT}_{3}$ receptors. Oocyte membrane may also contain $5-\mathrm{HT}_{2}$ receptor sites.

This study was supported by a grant from The Rockefeller Foundation. The 5-HT analogs were gifts from Glaxo, Sandoz, CIBA-Geigy, Roussel UCLAF, Farmatalia, Lilly, and Bristol-Myers.

Early cleavage and the role of the macromeres in the development of the polyclad flatworm Hoploplana. BARBARA C. Boyer and GWendolyn A. Wallace (Union College).

Blastomere deletion experiments were used to investigate the role of the macromeres at the eight-cell stage (first quartet) in the development of the polyclad turbellarian Hoploplana inquilina. In particular, eye development, general morphology, and determination of the embryonic axes of symmetry were examined after deletion of macromeres $1 \mathrm{~A}$ or 1C, IB or ID, two adjacent macromeres, three macromeres, and all four macromeres.

Normal Müller's larvae resulted in $31 \%$ of cases in which $1 \mathrm{~A}$ or IC was deleted, and in 23\% after removal of 1B or 1D. Macromere deletions usually did not lead to loss of eyes (no more than one quarter of any experimental category included one-eyed or eyeless larvae), but often did result in formation of supernumerary eyes. The occurrence of larvae with three or more eyes ranged from one quarter of experiments in which $1 \mathrm{~A}$ or $1 \mathrm{C}$ was deleted, to $77 \%$ after deletion of all four macromeres. Normal morphology was compatible with loss of no more than one macromere, while deletion of three and four macromeres resulted in almost all of the larvae exhibiting the "swollen syndrome," characterized by spherical shape, abnormal tissues, and fluid accumulation. Following deletion of $1 \mathrm{~A}$ or $1 \mathrm{C}, 92 \%$ of the larvae exhibited bilateral symmetry, although none did when three or four macromeres were killed. These results suggest the presence of an inhibitor of eye formation in the vegetal region that is more likely to be localized in the $1 \mathrm{~B}$ or $1 \mathrm{D}$ cell than in $1 \mathrm{~A}$ or $1 \mathrm{C}$. Results also indicate that normal morphology requires the presence of at least three macromeres and provide evidence that macromere-micromere interactions are involved in the determination of embryonic symmetry, in which the B or D quadrant is more likely to become dorsal than $\mathrm{A}$ or $\mathrm{C}$.

Scanning electron microscopic studies of four and eight-cell embryos suggest that the surface of one of the macromeres is smoother (less blebbed) than that of the other three, which may be associated with localization of morphogenetic determinants.

This work was supported by NSF grant DCB-8817760 and a grant from Earthwatch.

\footnotetext{
Involvement of $\mathrm{Ca}^{2+}$ channels in 5-hydroxytryptamineinduced oocyte maturation in Spisula. A. L. KADAM (The Population Council), P. A. KadAM, S. J. SEgAL, AND S. S. KOIDE.
}

Serotonin (5-hydroxytryptamine, 5-HT) induced in vitro maturation of Spisula oocytes. The present study was carried out to determine whether extracellular calcium is essential for 5-HT induction of maturation, and whether oocytes possess calcium channels regulated by the neurotransmitter.

5-HT induced germinal vesicle breakdown (GVBD) in Spisula oocytes suspended in ASW, but not in $\mathrm{Ca}^{2+}$-free ASW. When $\mathrm{Ca}^{2+}$ is added to $\mathrm{Ca}^{2+}$-free ASW to concentrations of 5, 10, 20, 30, and $50 \%$ ( $100 \%$ equivalent to $9.27 \mathrm{mM}$ ), the percent of GVBD induced with 5HT at a concentration of $5 \mu M$ was $2,30,64,86$, and $96 \%$, respectively. The calcium channel antagonists verapamil, nitrendipine, nifedipine, nimodipine, and $\mathrm{Cd}^{2+}$, at a concentration of $50 \mu M$, blocked 5-HTinduced maturation by $89,18,16,5$, and $1 \%$, respectively. The 1,4dihydropyridine agonist, BAY K8644, at a concentration of $10 \mu M$, did not induce GVBD in Spisula oocytes.

The capacity of 5-HT to stimulate ${ }^{45} \mathrm{Ca}^{2+}$ uptake by Spisula oocytes was determined. To a suspension of oocytes in $\mathrm{Ca}^{2+}$-free ASW,${ }^{45} \mathrm{Ca}^{2+}$ $(0.8 \mu \mathrm{Ci} / \mu \mathrm{mole})$ and test substances were added. The reaction mixture was incubated at $20-22^{\circ} \mathrm{C}$ for $10 \mathrm{~min}$; the reaction was stopped by adding $5 \mathrm{mM} \mathrm{KCl}$ buffer containing $3 \mathrm{~m} M$ EGTA, and the mixture was filtered through a GF/C filter. Radioactivity on the filter was measured using a liquid scintillation counter.

5-HT at concentrations of $0.5,1,2$, and $5 \mu M$ stimulated ${ }^{45} \mathrm{Ca}^{2+}$ uptake by Spisula oocytes. The uptake values were $0,5.2,17$, and 24.8 nmoles/mg protein, respectively, showing a dose response. The time course of ${ }^{45} \mathrm{Ca}^{2+}$ uptake at $20-22^{\circ} \mathrm{C}$, showed a lag period of $2 \mathrm{~min}$ followed by a dramatic increase at 5 and 10 min post-treatment. Verapamil, at a concentration of $10 \mu M$, inhibited 5-HT-stimulated $\mathrm{Ca}^{2+}$ uptake. The receptor-selective 5-HT agonists, alpha-methyl-5-HT (5$\mathrm{HT}_{2}$ ) and 8-OH-DPAT (5-HT $\left.\mathrm{HA}_{\mathrm{A}}\right)$, at a concentration of $5 \mu \mathrm{M}$, stimulated $\mathrm{Ca}^{2+}$ uptake by Spisula oocytes. Mianserin $\left(5-\mathrm{HT}_{1}, 5-\mathrm{HT}_{2}\right)$, at a concentration of $5 \mu \mathrm{M}$, blocked 5-HT-stimulated $\mathrm{Ca}^{2+}$ uptake.

In conclusion, extracellular $\mathrm{Ca}^{2+}$ is required for 5-HT induction of Spisula oocyte maturation. 5-HT acts by opening receptor-regulated calcium channels of Spisula oocytes.

BAY K 8644 was a gift of Miles, Inc. The study was supported by a grant from the Rockefeller Foundation.

\section{5-hydroxytryptamine receptor types on Spisula gametes.}

P. A. Kadam (The Population Council), A. L. KADAM, S. J. SEgal, AND S. S. KoIDE.

Receptors for serotonin (5-hydroxytryptamine, 5-HT) are classified into various types and subtypes. To establish the biologically functional 5-HT receptor types in Spisula gametes, selective agonists and antagonists for the various receptor types were tested for their capacity to influence Spisula oocyte maturation and sperm motility.

Oocyte maturation was assayed by examining the oocytes under a light microscope for dissolution of the germinal vesicle (GVBD); sperm motility was assessed by stimulation of cold-immobilized Spisula sperm. The drugs were tested at final concentration ranging from 1 to $50 \mu M$.

The order of decreasing potency of the 5-HT agonists to induce GVBD in Spisula oocyte was: $5-\mathrm{HT}=$ alpha-methyl-5- $\mathrm{HT}=8-\mathrm{OH}$ DPAT [8-hydroxy-2-(di-n-propylamino)tetralin]; both 2-methyl-5-HT and 5-CT (5-carboxyamidotryptamine) were inactive. The order of decreasing potency in stimulating sperm motility was: $5-\mathrm{HT}=$ alphamethyl-5-HT $=8-\mathrm{OH}-\mathrm{DPAT}>2$-methyl-5-HT $>5-\mathrm{CT}$. Phenylbiguanide and PAPP (LY-165, 163) were inactive on both gametes. The order of decreasing potency of 5-HT antagonists in blocking 5-HT induced oocyte maturation was: mianserin $>$ ketanserin $>$ s-(-)propanolol $>$ GR3832F > methysergide maleate. To block 5-HT stimulation of Spisula sperm motility, the order of decreasing potency of 5-HT was: mianserin $>$ ICS-250-930 > GR3832F $>$ ketanserin. 
These results indicate that Spisula oocytes possess biologically functional 5- $\mathrm{HT}_{1 \mathrm{~A}}$ and $5-\mathrm{HT}_{2}$ receptor sites, and sperm contain 5- $\mathrm{HT}_{1 \mathrm{~A}}$, $5-\mathrm{HT}_{2}$ and $5-\mathrm{HT}_{3}$ receptor sites. The presence of $5-\mathrm{HT}_{1 \mathrm{~A}}$ and $5-\mathrm{HT}_{2}$ receptor sites on the oocyte membrane was validated by the finding that mianserin (5- $\mathrm{HT}_{1}$ and 5- $\left.\mathrm{HT}_{2}\right)$ and BMY-7378 $\left(5-\mathrm{HT}_{1 \mathrm{~A}}\right)$ blocked 8-OHDPAT- $\left(5-\mathrm{HT}_{1 \mathrm{~A}}\right)$ induced oocyte maturation, and ketanserin $\left(5-\mathrm{HT}_{2}\right)$ and mianserin blocked alpha-methyl-5-HT- $\left(5-\mathrm{HT}_{2}\right)$ induced maturation. In conclusion, Spisula gametes possess 5-HT receptors of mixed or multiple types.

The 5-HT analogs were gifts from Glaxo, Sandoz, Ciba-Geigy, Rousse UCLAF, Farmatalia, Lilly, and Bristol-Myers. The study was supported by a grant from the Rockefeller Foundation.

\section{A fluorescent study of sensory neurons in normal and re- generating squid embryos. BARBARA E. MACLAY AND RACHEL D. FinK (Mount Holyoke College).}

We found two fluorescent lipophilic dyes to be vital markers specific for the ciliated sensory neurons of embryonic squid. The cationic membrane probes $\mathrm{DiIC}_{18}$ and $\mathrm{R} 1316$ were used to study the appearance, distribution, and regeneration of these neurons in embryos of Loligo pealei. Manually dechorionated embryos and hatched larvae were soaked in a $20 \mu \mathrm{g} / \mathrm{ml}$ solution of dye for $3 \mathrm{~min}$, rinsed in seawater, and viewed with epifluorescence. We followed neurogenesis in organ primordia such as tentacles and fins. After 2-5 days of outgrowth and differentiation of these structures, fluorescent staining revealed populations of peripheral neurons and an extensive network of axonal projections. All stained neurons had nonmotile cilia; those on the cells of the tentacles were numerous and long, whereas those in the fins were few and short. The presence of cilia on these cells may have facilitated uptake of the dyes, explaining their selectivity. By hatching, ciliated neurons were seen on most regions of the larva, including the epithelial lines on the head, along the mantle edge and surface, and on the siphon.

We established that larval squid completely regenerate fins 5-7 days following surgical removal. Soon after the appearance of any regenerant tissue, fully differentiated sensory neurons, complete with nonmotile cilia, can be stained. This differs from normal fin development where no staining of neurons can be seen until 3-4 days after first outgrowth. Possible models to explain this rapid ennervation of regenerated tissue include migration of pre-existing neurons from neighboring tissue, dedifferentiation and redifferentiation of cells at the wound site, and the presence of a stem cell population that differentiates into ciliated sensory neurons.

This work was supported by Steps, R. D. Allen, and S. W. Kuffler Fellowships of the MBL, an MHC Howard Hughes Summer Research Fellowship, and a William and Flora Hewlett Foundation Grant of Research Corporation to R.D.F.

Metalloproteinases of sea urchin embryo and sponge: detection by gelatin-substrate polyacrylamide gel electrophoresis. JAMES P. QUigLEY (SUNY, Stony Brook) AND PETER B. ARMSTRONG.

Tissue remodeling is a conspicuous feature of invasion, inflammation, wound repair, and embryonic and larval morphogenesis. Proteinases have been implicated in the degradation and turnover of extracellular matrix macromolecules presumed necessary for remodeling. Of particular interest are the enzymes responsible for the degradation of collagen, the principal structural element of most extracellular matrices. Two morphogenetic systems have been investigated for the presence of collagenases: the developing Arbacia embryo, and reaggregating Microciona tissue. In the first system, processes of cellular ingression. cell migration across basal lamellae, and invagination are prominent. In the second system, dissociated cells reaggregate, then sort out to re- constitute normal tissue morphology. Collagenases were identified by subjecting tissue extracts and conditioned seawater to SDS-polyacrylamide gel electrophoresis (non-reducing conditions) on gels containing gelatin. Enzymatic activity was detected as bands of clearance of the gelatin from the polyacrylamide gel matrix following removal of the SDS, incubation in buffers containing calcium (room temperature, 3648 h.), and staining with Coomassie blue. Arbacia embryos showed three prominent gelatinases that migrated with approx. molecular masses of 65,45 , and $40 \mathrm{kDa}$. Gastrula and prism stage embryos released gelatinases of approx. 70 and $80 \mathrm{kDa}$ into the seawater. The activity of the 65 and $40 \mathrm{kDa}$ tissue gelatinases increased, and that of the $45 \mathrm{kDa}$ tissue gelatinase decreased, during development. Reaggregating Microciona tissue released several gelatinases into the seawater; one of them, of approx. $85 \mathrm{kDa}$, was the most prominent. All of the Arbacia enzymes and the $85 \mathrm{kDa}$ Microciona enzyme were EDTA-sensitive and PMSF-insensitive. Some of the low molecular mass Microciona gelatinases were EDTA-insensitive and PMSF-sensitive. None of the Arbacia enzymes had detectable caseinolytic activity,

Supported by NIH grant No. GM35185.

\section{Comparative aspects of gossypol action. SHELDON SEGAL (The Rockefeller Foundation) AND HIROSHI UENO.}

Gossypol (gp) has both anti-sperm and anti-virus activity in vitro (Polsky et al. 1989, Contraception 39: 579-587). Consequently, gp may have an application in humans as an active ingredient of a vaginal protective cream (VPC). Factors influencing the use of $g p$ in this manner were studied. The biological assay employed was the effect on motility and fertilizing capacity of Arbacia sperm (Segal et al. 1985, Biol. Bull. 169: 543-544). Biological activities of gp solutions in filtered seawater, prepared from dilutions of gp in two vehicles, ethanol (roh) and cyclodextran (cd), were compared. Gp/roh concentrations of $25 \mu M$ or higher are $100 \%$ effective in destroying the fertilizing capacity of $\mathrm{Ar}$ bacia sperm within $3 \mathrm{~min}$. Sperm treated with $50 \mu M$ or $25 \mu M \mathrm{gp} / \mathrm{cd}$ retain about $30 \%$ fertilizing capacity. The anti-oxidant glutathione (gt) is proposed as an additive to a VPC in order to extend its shelf-life under non-refrigerated, non-lightproof conditions. In the Arbacia sperm test, gt at a concentration of $200 \mu M$ has no effect on sperm motility, nor does it reduce the activity of solutions of $\mathrm{gp} / \mathrm{roh}$. The minimal effective dose for $100 \%$ inhibition of motility is higher for human sperm than for Arbacia sperm. Twenty-five $\mu M \mathrm{gp} / \mathrm{roh}$ is required to inactivate fully a normal human sperm sample within $15 \mathrm{~min}$, a time at which control samples retain their motility. Immobilization of human sperm within $3 \mathrm{~min}$ is achieved with a $\mathrm{gp} / \mathrm{roh}$ concentration of $200 \mu \mathrm{M}$. Gp/roh retains full spermicidal activity when exposed to ethylene oxide under conditions used for gas sterilization. These observations suggest that a VPC containing gp/roh at a concentration of $200 \mu M$ or higher, incorporating the anti-oxidant gt, and prepared in an ointment base vanishing cream that can be sterilized with ethylene oxide, may be an effective spermicidal/virucidal modality.

\section{Interphase particulate tubulin revisited. KATHY A. SU- PRENANT (University of Kansas, Lawrence).}

I have repeated the experiments of Weisenberg ( $J$. Cell Biol. 1972, 54: 266-278) in order to identify the source of the particulate and sedimentable pool of tubulin described in surf clam (Spisula solidissima) oocytes. Spisula oocytes were homogenized at $21^{\circ} \mathrm{C}$ in 10 volumes of 1 $M$ hexylene glycol, $0.01 \mathrm{M}$ potassium phosphate at pH 6.2 (HG1) and centrifuged at $5000 \mathrm{rpm}(\mathrm{JA}-20)$ for $30 \mathrm{~min}$ at $4^{\circ} \mathrm{C}$ through a cushion of $10 \%(\mathrm{w} / \mathrm{v})$ sucrose in $\mathrm{HG} 1$. Tubulin was extracted from the pellet with 2 volumes of ice-cold $0.1 \mathrm{M} \mathrm{KCl}, 0.01 \mathrm{M}$ potassium phosphate, and $0.2 \mathrm{mMGTP}$ at $\mathrm{pH} 7.0$, and the sample was clarified by centrifuga- 
tion at $10,000 \mathrm{rpm}$ for $10 \mathrm{~min}$. The tubulin in the soluble and sedimentable fractions was analyzed by a quantitative immunoblot with a monoclonal antibody against $\alpha$-tubulin (DM-1 $\alpha$ ). Approximately 6$10 \%$ of the total tubulin in the oocyte sedimented at low $\mathrm{g}$ forces under these extraction conditions. The "tubulin-containing structure," described by Weisenberg as a $10-20 \mu \mathrm{m}$ granular sphere, was identified by phase and differential interference contrast microscopy as the nucleolus, but is not the source of the particulate tubulin. The sedimentable tubulin fraction comprised short microtubules $(5-10 \mu \mathrm{m})$ associated with membranes, and an amorphous granular material, as well as an aggregated and unidentified form of tubulin. The amount of particulate tubulin was determined during the first meiotic cell cycle following parthenogenetic activation with $\mathrm{KCl}$. Extracts were prepared at 3-min intervals and analyzed for soluble and particulate tubulin by the immunoblot assay. The total amount of particulate tubulin decreased by $30 \%$ during germinal vesicle breakdown and formation of the first meiotic apparatus. This decline in the sedimentable tubulin fraction during the first meiotic cell cycle is presently inexplicable.

\section{Nicotinamide suppresses Arbacia punctulata develop- ment. WALTER TROLL (New York University Medical Center) AND GERALYN CORCORAN.}

Nicotinamide is one of a group of compounds that inhibits the formation of poly(ADP)ribose (PADPR), a polymer formed by dividing cells. The role of PADPR in cell division and differentiation can be studied by observing the effects of inhibitors of its formation. In this study, the effect of three PADPR inhibitors, nicotinamide, benzamide, and 3-aminobenzamide, on Arbacia punctulata development was investigated. We noted, when these PADPR inhibitors were added immediately after fertilization of Arbacia, that differentiation to plutei was blocked 2 days after fertilization, and that normal division proceeded to gastrula over the first $20 \mathrm{~h}$. The complete blocking of a differentiation step suggests that a specific piece of information on DNA has been deleted and is responsible for this differentiation. Specific deletion of oncogenes in NIH-3T3 cells has been noted on addition of nicotinamide and other PADPR inhibitors (Nakayasu et al. 1988, Proc. Natl. Acad. Sci. USA 85: 9066-9070). The blocking of differentiation mimics the deletion of genetic information provided by an oncogene and may serve as an assay to test other substances that may be capable of interfering with cancer development.

Supported by NIEHS Center Grant ES 00260 and Superfund Grant 1 P42 ES 048995.

\section{Binding of gossypol and its analog to sperm proteins from Arbacia, Chaetopterus, and Spisula. H. UENO (Rocke- feller University) AND S. J. SEGAL.}

Gossypol, a known anti-fertility agent, also exhibits anti-parasite and anti-viral activities (Eid et al. 1988, Exp. Parasitol. 66: 140-142; Polsky et al. 1989, Contraception 39: 579-587). To elucidate the mode of action of gossypol, the biological activity of its metabolite, gossypolone, was studied. We also attempted to identify protein components in the sperm that might be involved in gossypol recognition, uptake, and inactivation. To identify such protein components, gossypol affinity resins were developed, either through the hydroxyl group via ether linkage, or through the aldehyde group via Schiff base linkage, stabilized by $\mathrm{NaBH}_{4}$ reduction.

Gossypolone inhibits both the motility and fertilizing capacity of $\mathrm{Ar}$ bacia and Spisula sperm. The dose of gossypolone required to inhibit $50 \%$ fertilization by Arbacia sperm is $5 \mu M$. A slightly lower dose (1 $\mu M$ ) is needed for gossypol. However, gossypolone shows no effect on oxygen uptake, whereas gossypol $(17 \mu \mathrm{M})$ acts as an uncoupler and causes a three-fold enhancement of oxygen uptake. The results suggest that the aldehyde moiety is required for inhibition of sperm motility, and that the $1-\mathrm{OH}$ position is involved in oxygen uptake, presumably due to oxidation at this location.

Protein extracts from Arbacia, Chaetopterus, and Spisula sperm were prepared in a solution containing $1 \%$ Triton X-100, $0.5 \%$ deoxycholate, and $0.1 \%$ SDS (TDS). SDS-PAGE analyses of fractions, bound and unbound to gossypol affinity resins, show three predominant bands $(25,16$, and $14 \mathrm{~K})$ in bound fractions. Our results indicate that the gossypol affinity resin is a useful tool with which to identify gossypol binding protein components, not only in sperm, but also from other cells. Analysis and identification of gossypol binding proteins may have useful pharmacological implications.

This study was supported by the Rockefeller Foundation.

\section{General Physiology}

\section{Arachidonate and docosahexanoate as messengers in stimulus-response-coupling: evidence for effects of $G$ - proteins in marine sponge aggregation. GIULIA CELLI, Jonathan McMenamin-Balano, SteVen Abram- SOn, KathleEN Haines, JoAnNa Leszczinska, and Gerald Weissmann (Marine Biological Labo- ratory).}

The reaggregation of dissociated cells of Microciona prolifera in seawater is an example of stimulus-response coupling during which the twin signals, diacylglycerol and raised cytosolic $\mathrm{Ca},[\mathrm{Ca}]_{i}$, are generated (review in Weissmann et al. 1988, Biochim. Biophys. Acta. 960: 351$364)$. We have now found that arachidonic acid (20:4) and docosahexanoic acid (22:6) - at EC s0 $_{\text {'s }}$ of 10-50 $\mu M$ - enhance the aggregation of marine sponge cells exposed to suboptimum amounts of $\mathrm{Ca}$ and ionomycin ( $5 \mathrm{~m} M, 1 \mu M$, respectively), while having no effect on aggregation provoked by phorbol myristate acetate (a surrogate for diacylglycerol) and ionomycin. This behavior of 20:4 and 22:6 (the major fatty acid of Microciona phospholipids) was mimicked by fluoroaluminate or sodium orthovanadate ( $5 \mathrm{~m} M, 3 \mathrm{~m} M$, respectively) - agents that activate the $41 \mathrm{kDa}$ alpha subunit of GTP-binding proteins of mammalian cells. Indeed, 20:4 enhanced the binding of GTP $\gamma{ }^{35} \mathrm{~S}$ to membranes of mammalian cells $\left(\mathrm{EC}_{50}=50 \mu M\right)$, and autoradiograms of membrane preparations of marine sponge cells showed radio-GTP binding to two classes of proteins: $36-38 \mathrm{kDa}$ and $19-20 \mathrm{kDa}$. The latter resembled ras proteins in gels from porcine brain and human neutrophils. Moreover, ADP ribosylation of membranes from marine sponges showed twin substrates at $36-38 \mathrm{kDa}$, the ribosylation of which was enhanced by pertussis toxin. Finally, since G-proteins are often linked to phospholipases $\mathrm{C}$ in stimulus-response coupling, we exposed cells to protein 1 of the gonococcus phospholipase C. Protein 1 is a specific inhibitor not only of exocytosis, but also of phosphatidyl choline. Aggregation provoked by $20: 4$ and $22: 6$ was completely inhibited by protein $1(1 \mu M)$. The data suggest that since sponge cells cannot metabolize $20: 4$ or $22: 6$ to prostaglandins or leukotrienes, these fatty acids act as direct messengers which can activate the $\mathrm{G}$ proteins of stimulus-response coupling.

\section{Opioids in invertebrates. GIUSEPPE D'AlEsSIO, RENATA Piccoli, ANd Nello Russo (Department of Organic and Biological Chemistry, University of Naples, and Zoological Station, Naples, Italy)}

Almost 15 years after the discovery of opiate receptors and endogeneous opioid peptides in vertebrate animals, the question of the presence of opioids in invertebrates has not been satisfactorily answered. 
Opiate receptors have, in fact, been found and characterized in invertebrates (Zipser et al. 1988, Brain Res. 463: 296-304), and a wealth of mostly immunohistochemical data have been produced on opioid-like immunoreactivity in invertebrates, from Protozoa to Urochordata. However, no reproducible and conclusive results on the isolation and chemical characterization of opioid peptides from invertebrates are available to date. Recently, we approached the problem at the genomic and the transcription levels, with the aim of identifying sequences homologous to the coding sequences of vertebrate opioid genes. By Southern blotting, we detected hybridization signals, suggesting that Ciona intestinalis DNA includes sequences homologous to the pro-enkephalin precursor gene; by in situ hybridization we found that this gene appears to be expressed in the neural gland (R. Piccoli, N. Russo, A. Spagnuolo, T. Renda, and G. D'Alessio, in prep.). Similar results were obtained with a mollusc (Octopus, unpub.) and a cnidarian (Calliactis, in collaboration with L. Cariello and coworkers at the Zoological Station, Naples).

In an attempt to expand our research to animals not available in the Bay of Naples, we prepared DNA from Styela partita, a tunicate, and from a mollusc, Mytilus edulis. Protocols were defined for obtaining suitable DNA preparations in good yields. DNA was then digested with Eco R1 and with (Eco R1 + Bam H1), and the digests analyzed by Southern blotting with a probe from Xenopus pro-enkephalin gene labelled with ${ }^{32} \mathrm{P}$ at a high specific activity. No clear discrete bands of hybridization were detected, which at least in the case of Styela would be surprising, considering its relation to Ciona

\section{Does calsequestrin facilitate calcium diffusion along the endoplasmic reticulum of eggs? LIONEL F. JAFFE (Ma- rine Biological Laboratory).}

I would suggest that egg calsequestrin (Henson et al., $1989 \mathrm{~J}$. Cell Biol. 109: 149-161)—unlike its muscle counterpart-is freely diffusable within the endoplasmic reticulum (e.r.) and is thus able to facilitate calcium movement over long distances. Such facilitation could aid in the generation and control of steady, free calcium gradients within the cytosol of eggs. (Compare Speksnijder et al., 1989 Proc. Natl. Acad. Sci. USA 86: in press.) Egg calsequestrin, a $50 \mathrm{kDa}$ hydrophilic protein able to bind about 15 calcium ions per molecule, seems well suited to this role. From the energetics of the well known calcium ATPase of muscle, it can be estimated that free calcium within egg e.r. does not exceed about $1 \mathrm{~m} M$. From the total calcium within fertilized sea urchin eggs (known to be about $2 \mathrm{mM}$ ), and the volume fraction of e.r. within such eggs (morphometrically estimated to be about $5 \%$ ), as well as cytochemical evidence that most of the calcium in fertilized sea urchin eggs lies within the e.r. (Poenie et al., 1987; J. Histochem. Cytochem. 9: 939956), the total calcium within egg e.r. can be estimated as well over 10 $\mathrm{m} M$. If these estimates are correct, and if egg calsequestrin is indeed freely diffusable, then most calcium movement along the e.r. can be shown to occur while the ion is bound to calsequestrin.

\section{Calcification and proton transport in algae. TED MCConnaughey (Marine Biological Laboratory).}

Inward proton currents exceeding $10 \mu$ mols $\mathrm{m}^{-2} \mathrm{~s}^{-1}$ were measured at localized regions of the rhizoid of the marine alga Acetabularia mediterranea, using a vibrating proton-specific microelectrode. These currents are light and $\mathrm{Ca}^{2+}$-dependent, and are associated with $\mathrm{CaCO}_{3}$ deposition. Similar light and $\mathrm{Ca}^{2+}$-dependent currents were observed in the calcareous fresh water alga Chara corallina. A combination of techniques (electrophysiology, electron microprobe, isotope ratio mass spectrometry, ${ }^{14} \mathrm{C}$ isotopic labelling, and studies using buffers to affect proton and carbon transport) suggests that proton uptake occurs through ATP-driven electroneutral $2 \mathrm{H}^{+} / \mathrm{Ca}^{2+}$ exchange, which raises the local extracellular $\mathrm{Ca}^{2+}$ concentration and $\mathrm{pH} . \mathrm{CO}_{2}$ then diffuses from the cell into the alkaline extracellular environment, and precipitates with $\mathrm{Ca}^{2+}$. The protons taken up by the cell derive from $\mathrm{CO}_{2}$ hydration and ionization.

For each $\mathrm{CaCO}_{3}$ precipitated, the plant takes up two $\mathrm{H}^{+}$. These move through the plant and are expelled at a separate surface, giving rise to electrical gradients and currents through the plant. Upon expulsion from the cell, the two $\mathrm{H}^{+}$convert two $\mathrm{HCO}_{3}{ }^{-}$to two $\mathrm{CO}_{2}$, which are taken up by the plant. Since one $\mathrm{CO}_{2}$ is subsequently consumed in calcification, there is a net gain of one $\mathrm{CO}_{2}$ for photosynthesis when this physiology works efficiently (at pH about 8 , typical of seawater). Viewed in this context, rapid and massive calcification by aquatic plants and algae-invertebrate symbioses is mainly a proton-generating mechanism for stimulating the photosynthetic utilization of bicarbonate.

\section{Regulation of insulin release from pancreatic islet cells by norepinephrine and neuropeptide Y. SHARON L. MIL- GRAm, John K. MCDOnald, AND BRyAn D. NoE (Emory University School of Medicine, Atlanta, GA 30322).}

Insulin secretion from pancreatic islet beta cells is regulated by nutrient, hormonal, and neuronal secretagogues. Nerve fibers innervating pancreatic islets of a number of species contain both neurotransmitters and neuropeptides. Interactions between transmitters and peptides in modulating islet hormone release are poorly understood. We have recently demonstrated that a peptide with HPLC and immunoreactive characteristics identical to neuropeptide $\mathrm{Y}$ (NPY) is found in nerve fibers in anglerfish pancreatic islets. NPY is a 36 amino acid peptide having widespread distribution throughout the central and peripheral nervous systems in various species and is often co-localized with norepinephrine (NE) in catacholaminergic nerve terminals. Therefore, we are investigating the possibility that NPY and NE may interact in regulating basal- or glucose-stimulated insulin secretion from anglerfish islet beta cells.

Islets were decapsulated, minced, and dispersed using dispase. Dispersed cells were cultured for a minimum of $72 \mathrm{~h}$ in RPMI 1640 containing all amino acids, $2 \mathrm{mM}$ glucose, and $10 \%$ fetal calf serum. Cells $\left(3-5 \times 10^{6}\right)$ were suspended and perifused in $10 \mathrm{mM}$ HEPES buffer containing $3 \mathrm{mM} \mathrm{CaCl}, 2 \mathrm{mM}$ glucose, and nutrient or neural secretagogues. Perifusate fractions were collected, and aliquots were assayed for insulin by RIA. Glucose-stimulated insulin secretion in a dose-dependent fashion. Maximal increases of 2.5-3 fold over basal levels were achieved with 11.0 and $16.7 \mathrm{~m} M$ glucose, respectively. NE inhibited insulin release caused by $11 \mathrm{~m} M$ glucose in a dose-related manner, with complete inhibition accomplished at $50 \mathrm{n} M$ NE. NE perfusion $(10 \mathrm{n} M)$ with basal glucose $(2 \mathrm{mM})$ also reduced basal insulin release by 33 $36 \%$. Administration of NPY $(1 \mu M)$ with $2 \mathrm{~m} M$ glucose stimulated insulin secretion $53 \%$. The effects of porcine NPY on glucose-stimulated insulin release and the potential interactions of NPY and NE are currently under investigation.

Supported by NSF grant DCB-8700843.

Analysis of edge birefringence observed near refractive index steps in myofibrils and $\mathrm{KCl}$ crystals using high resolution polarized light microscopy and spatial Fourier filtering. Rudolf OldENBOURG AND SHINYA INOUÉ (Marine Biological Laboratory). 
In conventional polarizing microscopes, vertebrate striated muscles show a pattern of alternating strongly birefringent A-bands and weakly birefringent I-bands; both bands exhibit positive birefringence (slow axis parallel to fiber axis). Each I-band is bisected by a less birefringent Z-line. When observed at high resolution with polarization rectifiers, the Z-band appeared split into three narrow zones, with two outer positively birefringent zones flanking a central negatively birefringent, or isotropic, zone. In addition, each interface between the A- and I-bands seemed to be composed of two narrow zones of different birefringence values. These observations were made upon muscle fibers suspended in standard salt solutions that had a lower refractive index than the filaments in the fibers. When the medium was replaced with one that matched the refractive index of the filaments, the A- and I-bands each appeared uniform and exhibited their characteristic high and low intrinsic birefringence.

The appearance of narrow birefringent zones near refractive index steps in muscle is similar to the patterns observed at the edges of isotropic crystals: the side with the high refractive index medium exhibits what appears to be a thin birefringent layer with the slow axis parallel to the interface; and the low index side exhibits a birefringent layer with the slow axis perpendicular to the interface.

We explored the phenomenon of edge birefringence with inhibition measurements using thin $\mathrm{KCl}$ crystals and myofibrils of rabbit psoas muscle. Video images of myofibrils, several sarcomeres long, were recorded and processed using a desktop computer. Spatial filtering was applied by multiplying the Fourier spectrum of the fiber image with a mask retaining only those frequencies that were an integral multiple of the inverse sarcomere length. The back transform of the filtered spectrum gave the fiber image averaged over all sarcomeres.

Supported by grants NIH R37 GM 31617 and NSF DCB8518672.

\section{Identification of myosin in dogfish shark and sea robin lens epithelium. NANCY S. RAFFERTY (Northwestern University), KRIS LOWE, KeEN A. RAFFERTY, AND SEYMOUR ZigmaN.}

We have been comparing the contractile proteins in the lenses of selected species with varying modes of accommodation for near-point focus. Marine fish and shark lenses, and the suspensory apparatus of those lenses, were examined for actin and myosin. SDS-polyacrylamide gel electrophoresis of extracts of these tissues, followed by Western blots with actin and myosin antibodies, were used to identify the proteins. We also used double-labeled immunofluorescence microscopy.

Standard methods of electrophoresis on $7.5 \%$ gels and blotting onto nitrocellulose paper were employed. The papers were incubated in a pan-myosin monoclonal antibody (Amersham) or in a polyclonal actin antibody (made in rabbits in N.S.R.'s laboratory). Reaction with biotinylated sheep anti-mouse or donkey anti-rabbit immunoglobulins were followed by streptavidin-peroxidase, (Amersham). The binding was visualized by incubation in 4-chloro-1-naphthol and $\mathrm{H}_{2} \mathrm{O}_{2}$. The same probes were used for immunofluorescence techniques, except that streptavidin-fluorescein and rhodamin phalloidin were substituted for the peroxidase on epithelial whole mounts.

A single band of about $200 \mathrm{kDa}$ appeared in Western blots of the lens epithelial cells of both the shark and the sea robin, and in the suspensory ligaments of the shark. This band identifies the myosin in these tissues as myosin-II. Immunofluorescence microscopy revealed the myosin at the plasma membranes and perinuclear regions of the epithelial cells.

Thus, lens epithelial cells, and the structures that translate the lens for accommodation in these aquatic animals, have components of a contractile system. We suggest that they may be involved in maintaining lens shape and resisting excessive deformation of the epithelium through tonic contraction of actin and myosin filaments.

This research was supported by NIH grant EY 00698.
Spontaneous coagulation of Limulus amebocyte releasate in the absence of detectable endotoxin. FREDERICK R. RICKLES (University of Connecticut School of Medicine), Peter B. Armstrong, Carl A. CARTA, AND JAmEs P. QUigley.

Activation of blood coagulation is a fundamental host response to trauma and inflammatory stimuli. The formation of a blood clot can delimit the inflammatory response. In higher mammals, these reactions have been well characterized, and a variety of endogenous and exogenous "activators" and inhibitors of the coagulation protease cascade have been described. In the most completely studied of all invertebrates, the horseshoe crab Limulus polyphemus, previous work has suggested that initial activation of a proclotting enzyme by gram-negative, bacterial endotoxin is obligatory for physiologic coagulation. In most of the previous studies of Limulus proteins, investigators have used Limulus amebocyte lysate (LAL), material prepared by distilled water lysis of blood cells (amebocytes) in the presence of the inhibitor n-ethylmaleimide (NEM). We report here the first biochemical evidence for an endotoxin-independent coagulation sequence in Limulus; its terminal components appear identical to those of the classical, endotoxin-mediated sequence in LAL described by others. Exocytosis and gelation of the granule contents of the amebocytes were observed in blood collected, without inhibitors, directly into heat-treated, endotoxin-free dishes. The gel and residual gel supernate (sn-1) were recovered from the dishes, a second supernate (sn-2) was recovered following centrifugation of the gel, and the proteins in these fractions were analyzed by SDS-polyacrylamide gel electrophoresis (reducing conditions) and western blotting. Two different rabbit antibodies prepared against purified Limulus coagulogen (the clottable protein) were used as immunologic probes. Contaminating endotoxin was excluded as a variable by testing all of the materials with an LAL sensitive to $10 \mathrm{pg} / \mathrm{ml}$ of endotoxin. A protein with a molecular radius $(\mathrm{Mr})$ appropriate for the coagulogen $(\sim 24 \mathrm{kDa})$ was observed in extracts of intact, granulated amebocytes, and in both supernatants. Little or no $24 \mathrm{kDa}$ protein remained in the "spontaneous" gel. A new protein band with an $\mathrm{Mr}$ appropriate for the coagulin, the matrix protein of the traditional LAL gel $(\sim 17 \mathrm{kDa})$, was observed in the resolubilized "spontaneous" gel. When probed with either of the antisera to coagulogen, both the $24 \mathrm{kDa}$ and the $17 \mathrm{kDa}$ proteins were detected. We interpret these data as evidence for an endotoxin-independent coagulation system in Limulus, perhaps mediated by one or more NEM-sensitive proteases not active in traditional preparations of LAL. These proteases use the same clottable protein (coagulogen) as substrate.

Supported by the Veterans Administration (Research Service) and grants from the Department of Health and Human Services (CA 22202; GM35185), the American Heart Association (83-957), the American Cancer Society (CH321), and the National Science Foundation (PCM80-24181).

Secretion of Microciona prolifera aggregation factor $(M A F)$ is required for marine sponge aggregation: quantitative analysis by means of a new assay for maF. William Riesen, Giulia Celli, Jonathan McMenamin-Balano, and Gerald Weissmann (Marine Biological Laboratory).

Since 1982, we have studied the reaggregation of marine sponge cells as an example of stimulus-response coupling during which the twin signals of diacylglycerol (protein kinase $\mathrm{C}$ ) and increments of cytosolic $\mathrm{Ca}$ are generated in response to such stimuli as phorbol myristate acetate (PMA) and ionomycin (review in Weissmann et al. 1988, Biochim. Biophys. Acta 960: 351-364). We have measured aggregation by re- 
cording light transmission through stirred suspensions of dissociated sponge cells (approx $10^{7}$ cells $/ \mathrm{ml}$ in $\mathrm{Ca}$ - and $\mathrm{Mg}$-free seawater containing $2.5 \mathrm{~m} M$ EDTA) after addition of $\mathrm{Ca} \pm$ ionomycin, or PMA + ionomycin. We have analyzed tracings of light transmission, with respect to rate, extent, and onset of aggregation, to monitor steps in the purification of MAF by methods modified from Humphreys et al. (1977, J. Supramol. Struct. 7: 339-351) and Misevic et al. (1982, J. Biol. Chem. 257: 6931-6936). Defining one kinetic unit ( $U_{k}$ MAF) as percent change in light transmission in one minute $(\Delta T / \mathrm{min})$, we report 100 fold purification of starting material by simple Ca precipitation ( 30 $\mathrm{m} M$ ) and dissolution ( $5 \mathrm{mM}$ ), before density-gradient purification in cesium chloride. We confirmed that MAF fragments in EDTA inhibit MAF-induced cell/cell aggregation, and found that a $2.5 \mathrm{mM}$ excess of $\mathrm{Ca}$ over EDTA permits sponge aggregation in response to MAF, but that $2.5 \mathrm{mM} \mathrm{Mg}$ (which preserves MAF integrity) does not: evidence that $\mathrm{Ca}$ is required to "prime" cells for aggregation via a Ca-dependent receptor. Moreover, inhibitors of secretion (protein 1 of the gonococcus and calmidazolium, $1 \mu M$ and $40 \mu M$, respectively) inhibit aggregation produced by $\mathrm{Ca}$ and ionomycin (active aggregation), but not aggregation provoked by MAF (passive aggregation). The data provide functional support for our morphologic evidence that secretion of MAF is required for reaggregation of marine sponge cells, and that MAF appears to act both as a lectin and as a ligand.

In vivo vectorial labeling of scallop gill ciliary membranes by NHS-LC-biotin. L. WARREN AND R. E. STEPHENS (Marine Biological Laboratory).

To study the topology of proteins in the tubulin-rich membranes of scallop (Aequipecten irradians) gill cilia, we employed the water-soluble, membrane-impermeant probe NHS-LC-biotin to label surface-exposed $-\mathrm{NH}_{2}$ groups. Excised gills were exposed, for $30 \mathrm{~min}$, to $50 \mu \mathrm{g} /$ $\mathrm{ml}$ of NHS-LC-biotin in bicarbonate-buffered seawater, the gills were washed exhaustively with seawater, and the still-motile cilia were released by brief exposure to hypertonic seawater and then isolated and purified by differential centrifugation. The membrane plus periaxonemal matrix was solubilized by washing twice with $0.5 \% \mathrm{NP}-40$ or $1.5 \%$ octyl glucoside in $3 \mathrm{mM} \mathrm{MgCl}$ and $30 \mathrm{~m} M$ Tris- $\mathrm{Cl}$ ( $\mathrm{pH} 8.0$ ). The membrane extracts and the $9+2$ axonemes were analyzed stoichiometrically by SDS-PAGE and electroblotting, using HRP-avidin to detect biotinylated proteins. The major biotinylated membrane protein, having a molecular weight $>200 \mathrm{kDa}$, is only partially solubilized with NP. 40 (which leaves part of the membrane skeleton intact), but is almost fully solubilized with octyl glucoside, indicating that it is an axonemeassociated transmembrane linkage similar to that reported in Chlamydomonas moewusii flagella (Bloodgood 1988, J. Cell Sci. 89: 521531). Two other proteins of lower molecular weight ( 140 and $44 \mathrm{kDa}$ ) behave similarly. These biotinylated proteins represent a small fraction of the ciliary membrane proteins, suggesting that they are either derived from a subpopulation of cilia, or correspond to transmembrane elements that do not occur along the whole length of the axoneme. Membrane tubulin subunits of cilia labeled in vivo, or labeled after isolation, are not biotinylated, even though labeling of the axoneme in the latter case indicates that the reagent can enter the periaxonemal space. Therefore, these tubulin subunits must be integral to the membrane, rather than peripheral proteins or proteins derived from the periaxonemal matrix, and they are not exposed at the membrane surface.

Supported by USPHS Grant GM 20,644.

Near-UV effects on the thymidine incorporation into dogfish lens. Seymour Zigman, Kris LOWE, AND NANCY S. RAFFERTY (University of Rochester School

\section{of Medicine \& Dentistry, Rochester, New York} 14642).

The question of how near-UV radiation in the environment can damage the ocular lens so as to positively influence opacities has been considered from the standpoint of protein anomalies, but not from the standpoint that DNA may be damaged. The hypothesis that DNA is susceptible to such UV energy in the most anterior region, the lens epithelial cells, was tested by this work. Fresh dogfish (Mustelus canis) eyes were dissected to remove the cornea, and put into Ringer's medium so that the lens epithelium was facing upward toward a UV lamp emitting maximally at $365 \mathrm{~nm}$ with an intensity of $5 \mathrm{~mW} / \mathrm{cm}^{2}$ for up to $22 \mathrm{~h}$. Control eyes were treated and incubated similarly, but without UV-exposure. Observations of the presence or absence of visible opacities were made, as were histological observations, using lenses fixed in formalin:glutaraldehyde. The incorporation of ${ }^{3} \mathrm{H}$-thymidine into DNA was also measured. At $5 \mathrm{~h}$ of incubation, no changes in the abovestated parameters were observed. At $22 \mathrm{~h}$, mild opalescence was noted in the anterior superficial cortical region only of UV-exposed, but not control, lenses. Both pyknotic and swollen epithelial cells were observed. In numerous experiments, the UV-exposed epithelia incorporated significantly greater amounts of thymidine than controls. $\mathrm{H}_{2} \mathrm{O}_{2}$ production did not occur. This finding applied, whether the radiolabeled DNA was isolated using Qiagen resins, or if it was TCA precipitated and extensively washed. Qiagen resin tubes and agarose A50 M columns were employed to obtain DNA essentially devoid of RNA and protein. No molecular weight change was observed. Two possible explanations for these observations are proposed: (1) Swollen and pyknotic epithelial cells may result from osmotic insult due to UV-induced inhibition of NaK-ATPase (as observed in mammalian lens epithelium). (2) Thymidine incorporation is enhanced as the result of the repair of single strand breaks in DNA (as observed in tissue culture mammalian lens epithelial cells exposed to $\mathrm{H}_{2} \mathrm{O}_{2}$ ).

Support: N.E.I. (Ey00459); Research to Prevent Blindness, Inc.; Mullie and Pledger Funds (University of Rochester).

\section{Neurobiology}

Functional and structural consequences of activation of protein kinase $C(P K C)$ and injection of $G$-protein substrates of PKC in Hermissenda neurons. D. L. ALKON, C. Collin, I. Lederhendler, R. Etcheberigarray, P. Huddie, M. Sakakibara, S. Redlich, E. Yamoah, A. Papageorge, T. Nelson (Lab. Molec. Cell. Neurobiol., NINDS-NIH, Bethesda, MD).

In both Hermissenda and rabbit hippocampus neurons, PKC translocation accompanies and is probably responsible for long-lasting reduction of current flow through Ia and $\mathrm{Ic} \mathrm{K}^{+}$channels (Alkon 1989, Sci. Am. 7: 42-50). Persistent memory-specific changes of Hermissenda neuronal branches were also closely correlated with memory acquisition and $\mathrm{K}^{+}$current reduction. Finally, a $21 \mathrm{kDa}$ G-protein (CP20), a substrate for PKC in Hermissenda Type B cells, underwent learning-specific changes in phosphorylation (Neary et al. 1981, $\mathrm{Na}$ ture 293: 658-660; Nelson et al. 1989, Bioessays 10: 75-79). Here we show that, within $20 \mathrm{~min}$ of exposure to phorbol ester (PDBU) in the presence of light, Type B soma area increased $10.1 \pm 3.4 \%(\mathrm{n}=8)$, and projections ("blebs") consistently appeared on the soma surface, but not during exposure to inactive 4a-PDBU with light $(\mathrm{n}=6)$, or PDBU in darkness $(\mathrm{n}=9)($ ANOVA, $P<.001)$. Type $\mathrm{B}$ cells injected with $\mathrm{Ni}^{++} /$lysine showed reduced volume of terminal branches $(P<.001, \mathrm{n}$ =9) after the PDBU/light treatment, but not after the control treat- 
ments. Iontophoresis of CP20 potently reduced Ia by $40 \pm 6 \%$ and Ic by $53 \pm 9 \%, P<.001, \mathrm{n}=7)$, but heat-inactivated CP20 $(\mathrm{n}=8)$ or vehicle injections $(\mathrm{n}=8)$ did not. Iontophoresis of $v$-ras reduced Ia by $50 \pm 18 \%$ and $\mathrm{Ic}$ by $72 \pm 26 \%, P<.001, \mathrm{n}=7$, whereas $c$-ras injections increased the same $\mathrm{K}^{+}$currents by $43 \pm 9 \%$ and $63 \pm 12 \%, P<.001$, $\mathrm{n}$ $=7$. Vehicle injections were without effect. Thus, the G-protein substrates of PKC, when phosphorylated, may trigger molecular cascades with far-reaching structural and functional consequences in learning, development, and carcinogenesis.

\section{What is the origin of photoreceptor noise? ROBERT B. BARLOW AND EHUD KAPLAN (Marine Biological Lab- oratory).}

Photoreceptors are noisy in the dark. In the absence of light, both vertebrate and invertebrate photoreceptors produce discrete waves (quantum bumps) similar to those evoked by photon absorptions. The dependence of the rate of spontaneous bumps on temperature has been taken as evidence that they are produced by thermal isomerizations of rhodopsin. However, photoreceptor noise in the Limulus lateral eye can also be modulated by a circadian clock located in the brain. At night, efferent signals from the clock reduce the rate of spontaneous bumps without affecting those triggered by light.

How can neural activity change the effects of thermal energy without influencing those initiated by light? We investigated this question by measuring the effect of temperature on spontaneous activity of retinular and eccentric (second order) cells in the Limulus eye. Action potentials were recorded extracellularly from eccentric cells both day and night in situ, whereas quantum bumps were recorded intracellularly from retinular cells in the excized eye preparation, isolated from the circadian clock. We calculated the activation energies for eliciting spontaneous events from the Arrhenius relationship (log event rate vs. inverse absolute temperature).

We found that the average activation energy for eliciting action potentials from eccentric cells was $26.3 \pm 7.8 \mathrm{kcal} / \mathrm{mol}(\mathrm{n}=10)$ during the day and $27.9 \pm 6.5(\mathrm{n}=12) \mathrm{kcal} / \mathrm{mol}$ at night. The average activation energy for eliciting quantum bumps from retinular cells in vitro was $26.5 \pm 7.5 \mathrm{kcal} / \mathrm{mol}(\mathrm{n}=8)$.

Our results indicate that the circadian clock does not influence the energy required to elicit spontaneous events from the Limulus retina. Isomerization of rhodopsin by light requires energies $\geq 45 \mathrm{kcal} / \mathrm{mol}$, which is more than twice that required for the thermal production of quantum bumps by photoreceptors and action potentials by eccentric cells. Therefore, the spontaneous events cannot be caused by thermal isomerization of rhodopsin.

Supported by NSF grant BNS-8709059 and NIH grants EY-00667 and EY-4888.

\section{G-Proteins modulate calcium currents in Paramecium and Helix neurons. JUAN BERNAL (University of Con- necticut, Farmington, CT) AND BARBARA EHRLICH.}

Previously we reported that the calcium-dependent swimming behavior and the calcium action potential in Paramecium are modulated by G-proteins (McIlveen et al. 1987, Biol. Bull. 173: 445; Bernal and Ehrlich 1988, Biol. Bull. 175: 314). To test the hypothesis that both of these changes are due to modification of calcium channels, we measured the calcium currents in Paramecium calkinsi. In addition, the effects of G-proteins in Paramecium and in Helix aspersa neurons were compared. Although G-proteins modified the calcium currents in both cell types, we were surprised to find that the modifications were in opposite directions. To isolate the calcium currents, the cells were superfused with sodium-free solution containing potassium channel blockers (125 $\mathrm{m} M$ tetraethylammonium chloride, $5 \mathrm{mM}$ 4-aminopyridine, 5 $\mathrm{m} M$ 3,4-diaminopyridine and $10 \mathrm{mM} \mathrm{CsCl}$ ). The cells were studied using a two-microelectrode voltage clamp. The cell was held at -40 $\mathrm{mV}$ (Paramecium) or $-50 \mathrm{mV}$ (Helix) and depolarizing command pulses were applied to elicit the calcium currents. The compounds of interest were injected into the cell by pressure, with fast green as a dye indicator to ensure that the drug entered the cell. The effects of the injected compounds were studied only in those cells in which the holding and leakage currents were unaltered by the injection. We found that GTP $\gamma$ S, an analogue of GTP which binds to and activates $G$ proteins, enhanced the magnitude of the calcium current in Paramecium by 20 $90 \%($ mean $=40 \%)$. GTP $\gamma$ S reduced the calcium current in Helix neurons by the same amount. GDP $\beta$, which binds to and inactivates Gproteins, had the opposite effect of GTP $\gamma \mathrm{S}$ in Paramecium as well as in Helix. These results demonstrate that "T-type" calcium channels in Paramecium may be activated, whereas "L-type" calcium channels in Helix neurons may be inhibited by G-proteins.

J.B. is a Fellow of the American Heart Association, Connecticut Affiliate. B.E.E. is a PEW Scholar in the Biomedical Sciences.

\section{Preliminary molecular structure of FTX and synthesis of analogs that block $I_{C a}$ in the squid giant synapse. B. CHERKSEY, R. Llinas, M. SugimORI, AND J.-W. LiN (Dept. Physiology and Biophysics, NYU Medical Cen- ter, New York, NY 10016).}

FTX, a specific P channel blocker, is one of many channel blocking factors contained in the venom of the American funnel web spider. We have previously reported (Cherksey et al. 1988, Biol. Bull. 175: 304; Llinas et al. 1989, PNAS 86: 1686) on the use of FTX to construct an affinity gel for the isolation and characterization of $\mathrm{P}$-type $\mathrm{Ca}^{++}$channels from squid optic lobe and mammalian CNS.

Purification and structural analysis of FTX have been performed. FTX could not be adequately purified by reverse phase HPLC using acetonitrile:water gradients. FPLC on Superose indicated that FTX was of low molecular weight (200-400 Da), but did not effect an adequate purification. Anion exchange methods were ineffective. However, cation exchange on Mono $S$ permitted a high level of purification of FTX, with elution of the active factor at approximately $0.8 \mathrm{M} \mathrm{NaCl}$. Purified FTX exhibited a sharp UV absorption at $220 \mathrm{~nm}$. No ring (aromatic) structure was detected. The absorption at $220 \mathrm{~nm}$ showed a pronounced shift with acidification suggesting that FTX possesses a titratable amine group. FT-IR (Fourier transform infrared spectroscopy) indicated the presence of C-C, C-N, N-H, C-H, and the absence of $\mathrm{C}=\mathrm{O}$, absorptions. These results ruled out the possibility that FTX is a small peptide and suggest that it is a polyamine. The known polyamine glutamate channel blockers (which contain ring structures) are ineffective as presynaptic blockers.

On the basis of these results, model compounds were constructed with the general structure of arginine-polyamine:

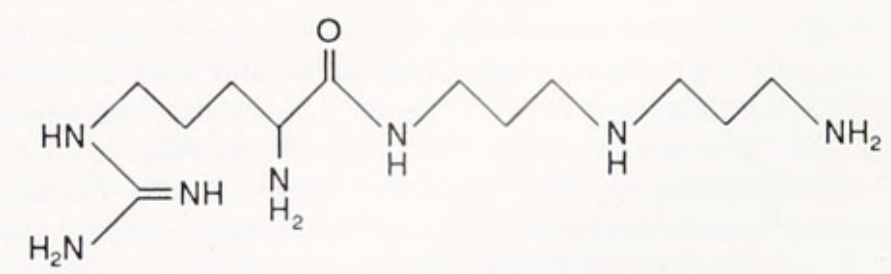

These compounds exhibited the selectivity of FTX, but not its potency. Compounds of the structure arginine-polyamine-arginine were ineffective as blockers. Thus, the free terminal amine is critical for efficacy, perhaps being the moiety that actually enters the pore of the channel. The arginyl group, perhaps via its strong charge, may act to secure the toxin in the channel. Therefore, the difference in potency between FTX and the model compounds may be due to the negative charge on 
the carbonyl of the latter, which, on the basis of FT-IR spectra, is absent from FTX.

\section{Arterial perfusion of FMRFamide-related peptides po- tentiate transmission at the giant synapse of the squid.} G. A. Cottrell, E. Stanley, M. Sugimori, J-W. LiN, AND R. LLINAS (Department of Physiology and Biophysics, NYU Medical Center, New York, NY 10016).

Peptides of the FMRFamide (Phe-Met-Arg-Phe- $\mathrm{NH}_{2}$ ) family (Price et al. 1987, Zool. Sci. 4: 395) have several different actions on molluscan neurones, and the naturally occurring $\mathrm{N}$-terminally extended forms can have different actions to the tetrapeptides on specified snail cells, suggesting the presence of more than one type of receptor (Cottrell and Davies 1987, J. Physiol. 382: 51). Last year we observed that FLRFamide ( $\mathrm{L}=\mathrm{Leu}$ ), micro-injected within the squid stellate ganglion, increases the rate of rise and amplitude of the EPSP and EPSC at the giant synapse in the absence of any observable effect on either the pre-synaptic spike or resting post-synaptic current (Cottrell et al. 1989, J. Physiol. 412: 64P).

We have now obtained a similar response by arterial perfusion of the ganglion with solutions containing FLRFamide, using the method of Stanley and Adelman (1984, Biol. Bull. 167: 467), and also by passing FLRFamide solutions directly into the stellate ganglion artery. The threshold for potentiation is less than $10 \mu M$. SDPFLRFamide (S $=$ Ser, $\mathrm{D}=$ Asp, $\mathrm{P}=$ Pro) has a similar effect, but we have been unable to observe any response with either Leu-enkephalin or the cephalopod peptide eledoisin. With both FLRFamide and SDPFLRFamide, potentiation of the EPSP usually wanes on exposure to the peptide for more than a few minutes. Another general feature is that the effect is more pronounced as the synapse is fatigued to a steady state by repeated high frequency stimulation. Potentiation with FLRFamide under these conditions can be greater than 2.5-fold. We must now determine which of the FMRFamide-related peptides occur in Loligo pealeii, and establish their modes of action in potentiating transmission at the giant synapse.

\section{Calcium currents recorded in cells of anterior pituitary} slices using the patch clamp technique. SUSAN A. DERiemer, MEYER B. JACKSON, AND ARTHUR KonNERTH (Max-Planck-Institut für biophys. Chemie, Göttingen, FRG).

The patch-clamp technique was applied to analyze $\mathrm{Ca}^{++}$-currents in cells found in slices of the rat anterior pituitary. Pituitary glands were removed from $15-30$ day old rats, and ultrathin $(60-100 \mu \mathrm{m})$ slices were cut on a vibratome. Single cells were visualized with an upright microscope equipped with a long-distance water immersion objective.

In the most commonly observed cell type (80-90\% of all cells), even at very negative holding potentials $(-120 \mathrm{mV})$, only non-inactivating $\mathrm{Ca}^{++}$-currents, similar to the high-voltage activated or L-type current, could be evoked. Substitution of $\mathrm{Ca}^{++}$by $\mathrm{Ba}^{++}$increased the amplitude and shifted the peak current from 20 to $10 \mathrm{mV}$. Addition of $20 \mu \mathrm{M}$ $\mathrm{Cd}^{++}$blocked the current, while $100 \mu \mathrm{MNi}^{++}$was ineffective. The dihydropyridine agonist BayK8644 increased the current, while nimodipine and nifedipine blocked it partially. A partial block was also seen with $\omega$-conotoxin $(50 \mu M)$. A second class of larger cells $(10-20 \%)$ was observed with both the non-inactivating and an additional, transient $\mathrm{Ca}^{++}$-current which was activated at holding potentials more negative than $-80 \mathrm{mV}$ (Carbone and Lux 1984, Biophys. J. 46: 413-418; Armstrong and Matteson 1985, Science 227: 65-67; Nowycky et al. 1985 , Nature 316: 440-443).

Immunocytochemistry, using antibodies to growth hormone (GH), prolactin ( $\mathrm{Prl})$, and lutenizing hormone ( $\mathrm{LH})$, showed that the primary cell type present in animals of this age contains growth hormone. Both prolactin and lutenizing hormone positive cells were distributed much more sparsely, but of the two, the Prl cells were larger. These results confirm and extend data obtained on cells in primary culture (DeRiemer and Sakmann 1986, Exp. Brain. Res. Ser. 14: 139-154.)

Use of this version of the patch clamp method, in combination with immunocytochemistry in situ, extends the possibilities for understanding the significance of functional differences in different cell types in regulating secretion and how the local environment of cells within the pituitary affects their responses.

Supported by a fellowship from the MBL, and grants from the March of Dimes and NSF (S.A.D.); DFG (SFB 236) (A.K.).

\section{Properties of detached nerve terminals from skate electric organ: a combined biochemical, morphological, and physiological study. M. DOWDALL, G. PAPPAS, AND M. Kriebel (SUNY, Health Science Center, Syra- cuse, NY 13210).}

The electric organs of the skate (Raja erinacea) dissociate into functional electrocytes when incubated with $1 \%(\mathrm{w} / \mathrm{v})$ collagenase. Dissociability of tissue is time and temperature dependent, and electrocytes with varying degrees of innervation can be produced according to conditions. At room temperature $\left(26^{\circ} \mathrm{C}\right)$ most electrocytes are denervated after $6 \mathrm{~h}$ of treatment. These have normal resting potentials $(-50 \mathrm{mV})$ and show a normal ultrastructure. After $2-4 \mathrm{~h}$ of treatment, innervation is present, and normal miniature end-plate potentials (MEPPs) and end-plate potentials (EPPs) can be recorded. Electron microscopy shows loosely adherent nerve terminals and detached terminals that can be concentrated by differential centrifugation. The Schwann cells migrate over newly exposed nerve terminal surfaces to encapsulate free terminals. Incubation at $6^{\circ} \mathrm{C}$ retards dissociation by 40 -fold, although the time characteristics of the MEPPs and EPPs remain normal during dissociation of normal-appearing nerve terminals from Schwann cells and electrocytes. After 4 days of collagenase treatment at $6^{\circ} \mathrm{C}$, electrocytes were washed several times, and isolated nerve terminals appeared in subsequent saline suspensions while MEPP frequencies fell and the denervated surface increased. Biochemical measurements, with choline acetyltransferase activity as a diagnostic nerve terminal marker and acetylcholinesterase activity as an auxillary marker, show that terminals became detached from electrocytes after $3-4$ days at $6^{\circ} \mathrm{C}$. This procedure produces isolated endings up to $5 \mu \mathrm{m}$ in diameter, which are recognizable, with Nomarski optics, by their size and included stationary particles (mitochondria). Moreover, these nerve terminals are readily distinguished from nucleated Schwann cells.

Supported by NSF 19694 and NIH NS25683.

\section{Very high resolution and dynamic stereo images of neu- rons. SHINYA INOUÉ (Marine Biological Laboratory), TED INOUÉ, RoBERT A. KNUdSON, AND RUdOLF OL- DENBOURG.}

We have devised a method for obtaining very high resolution stereoscopic images. A stack of 81 serial optical sections of Golgi-stained mouse neurons were recorded in $0.5-\mu \mathrm{m}$ steps using a $100 / 1.35 \mathrm{NA}$ Plan Apo lens (condenser NA $=1.1$ ). In the Image-I image processing computer, each image in the stack was compressed and sheared laterally by appropriate amounts in order to generate rotated "image cubes." The angles of rotation were chosen to provide the parallax needed for stereo imaging. To retain a clear sharp view of the large number of optical sections making up each cube projected into a single plane, a sharpening convolution was applied to each section, and then 
the minimum of each pixel gray value in adjoining sections was calculated. Images for the left and right eyes thus generated were placed at half height with the left image above the right in the video frame. To view in stereo, the left and right images were re-expanded vertically and projected as left- and right-circularly polarized images alternating at $120 \mathrm{~Hz}$ with a StereoGraphics projector. Complementary polarizing glasses worn by the viewers provide each eye with the left or right stereo image 60 times a second, giving rise to flicker-free stereoscopic images of an approximately $40-\mu \mathrm{m}$ cube. We demonstrated very high resolution, detailed arrangements of neuronal spines on the dendrites. Rotating stereo views of the neuron at moderately high resolution (40/0.95 NA) were also demonstrated.

Supported by grants NIH R37 GM 31617 and NSF DCB 8518672.

\section{Biphasic modulation of calcium-dependent potassium current in pituitary tumor cells examined with the per- forated patch clamp technique. RICHARD H. KRAMER (Columbia University) AND EDWIN S. LEVITAN.}

The pituitary tumor GH3 cell line is a model system for studying the actions of secretogogues, such as thyrotropin releasing hormone (TRH), which stimulate phosphatidylinositol hydrolysis and the formation of the intracellular messengers inositol trisphosphate $\left(\mathrm{IP}_{3}\right)$ and diacylglycerol. However, the electrophysiological effects of TRH have been difficult to study with the whole cell patch clamp method because the hormone response rapidly "washes out" of cells. To alleviate this problem, we have used the perforated patch configuration; the ionophore nystatin, contained in the patch pipette, is inserted into the membrane patch, providing a low-resistance pathway into the cell without causing washout of intracellular constituents. Using this configuration, we have elicited stable biphasic TRH responses (hyperpolarization followed by hyperexcitability). Under voltage clamp, the responses are characterized by an initial large increase in the outward current elicited during depolarizations, followed by a suppression of the outward current. The outward current, and both phases of the TRH response, are blocked by exposing the cell to the membrane-permeable calcium chelator BAPTA-AM, or by addition of charybdotoxin plus apamin, suggesting that modulation of $\mathrm{Ca}$-dependent $\mathrm{K}$ current accounts for both phases of the TRH response. The increase in Ca-dependent $\mathrm{K}$ current is thought to be due to $\mathrm{IP}_{3}$-gated $\mathrm{Ca}$ release from intracellular organelles. We suggest that the subsequent decrease in this current is indirect, due to TRH-induced inactivation of voltage-gated calcium channels (which we have observed) and consequent reduction of the calcium transient during depolarizations. In support of this hypothesis, we find that nimodipine, a dihydropyridine $\mathrm{Ca}$ channel blocker, selectively eliminates the suppression phase of calcium-dependent K current modulation.

\section{Ontogeny of serotonergic neurons in Hermissenda: a pre- liminary study. EBENEZER YAMOAH, AlAN M. KUZI- RIAN (Marine Biological Laboratory), AND CATHER- INE TAMSE.}

The nudibranch mollusc Hermissenda crassicornis is now in culture. As part of the effort to establish this invertebrate as a model system for neurobiological research, we are beginning an ontogenetic study of its nervous system. Applying function to morphology, we first undertook an immunocytological study to identify the developing serotonergic neurons in Hermissenda. We have observed that serotonin plays a major role in regulating feeding in adults, but one of our concerns in rearing this nudibranch is to maximize nutrition at all stages of development. Therefore, we have planned to investigate the role of these cells in feeding, and also to use them as markers documenting the developing nervous system in larvae and juveniles. Their putative role in metamorphic induction will also be examined.

Larvae raised from eggs that had been laid in the laboratory by field collected animals, were sampled on larval days: 1, 7, 14, 21, 28, and 35 . We fixed the larvae in $4 \%$ paraformaldehyde and processed them for immunocytochemistry using a goat antibody to serotonin (INCSTAR); this was followed by rabbit anti-goat biotinylated secondary antibody and labeling with strep-avidin conjugated FITC (Vector Labs). Juveniles (metamorphic day-6), and adult central nervous systems (CNS) were treated similarly. Observations and photo documentations were done using epifluorescence microscopy.

Areas of anti-serotonin labeling were present in larvae at hatching (larval day-1); moreover, during development, these areas became consolidated into easily recognizable cells (day-7, 14) and finally into definite ganglia (day-21, 28, 35). Specifically, in the early larval stages, the staining occurred in the velar region and in association with the velar and larval retractor muscles. A large serotonergic cell occurred in the metapodium (day-28) and, by day-21, several positively staining cells appeared in the vicinity of the newly formed eyes. By day-35 (metamorphically competent larvae), there were clearly identifiable ganglia ventral to each eye (putative cerebropleural ganglia). Juvenile Hermissenda showed characteristic and numerous, scattered serotonergic sensory cells (including some proximal axons) in the outer epithelium, including the oral tentacles, rhinophores, cerata, and tail. Staining for serotonin-containing cells in the adult CNS was only minimally successful, although we used previously proven methods and had obtained positive results with the larvae. The same minimal staining was obtained in both field-collected and lab-reared adults. The findings are suggestive of a seasonality associated with the levels of serotonin in adult Hermissenda, and further study of this possibility is being undertaken.

This research was aided in part by the microscopic facilities sponsored by Olympus and Zeiss at the MBL and supported by a grant to A.M.K. (RR03820, NIH).

\section{FTX blocks a calcium channel expressed by Xenopus oo- cytes after injection of rat brain $m R N A$. J.-W. LIN, B. RudY, AND R. Llinas (Dept. Physiology and Bio- physics, NYU Medical Center, New York, NY 10016).}

Funnel-web spider toxin (FTX) has been shown to block Ca conductances in cerebellar Purkinje cells and the presynaptic terminal of the squid giant synapse (Llinas et al. 1989, PNAS 86: 1689). To further characterize this toxin, we studied its effect on a calcium current $\left(\mathrm{I}_{\mathrm{Ca}}\right)$ appearing in Xenopus oocytes after injection of rat brain RNA. This current is insensitive to organic calcium channel blockers; i.e., dihydropyridine or $\omega$-conotoxin (Leonard et al. 1987, J. Neurosci. 7: 875). Two aspects of the effect of FTX on the expressed $\mathrm{I}_{\mathrm{Ca}}$ were examined: (1) the calcium-activated chloride current $\left(\mathrm{I}_{\mathrm{Cl}(\mathrm{Ca})}\right)$; and (2) currents carried by barium ions through calcium channels $\left(I_{\mathrm{Ba}}\right)$. In the presence of $1.8 \mathrm{mM}$ extracellular calcium, depolarizing pulses activated a mixture of inward and outward currents in the injected oocytes. Following the termination of the pulses, a prolonged tail of the $\mathrm{Cl}$ current could be recorded with its amplitude reflecting the magnitude of $\mathrm{Ca}$ influx activated during the depolarizing pulses. $\mathrm{I}_{\mathrm{CI}(\mathrm{Ca})}$ tail current exhibited a threshold of $-40 \mathrm{mV}$ and reached maximal amplitude between 0 and $+10 \mathrm{mV}$. FTX partially $(57 \%, \mathrm{n}=7)$ and irreversibly blocked the calcium activated chloride current without changing its voltage sensitivity, and had a minimal effect on $I_{\mathrm{Na}}$ and $\mathrm{I}_{\mathrm{K}}$. This block was concentration dependent; an $\mathrm{ED}_{50}$ was obtained at $1500 \times$ dilution of the crude venom, and the maximum blockade was typically achieved at $600 \times$ dilution (see also Llinas et al. 1989, these Abstracts). In the presence of $60 \mathrm{mM} \mathrm{Ba}^{++}$ and blockers of sodium and potassium currents, a voltage-activated 
inward current was recorded. This current $\left(\mathrm{I}_{\mathrm{Ba}}\right)$, presumably mediated by calcium channels, showed little inactivation, had a higher threshold $(-20 \mathrm{mV})$, and reached its peak amplitude between +20 to $+30 \mathrm{mV}$. FTX blocked $\mathrm{I}_{\mathrm{Ba}}$ partially and did not alter the time course of the current or its I-V characteristics. Furthermore, the extent of FTX partial block depended upon the level of RNA purification. The block is more extensive in the $I_{B a}$ expressed from poly $(A)$-mRNA $(66 \pm 9, n=4)$, than that from whole brain RNA $(41 \pm 11 \%, \mathrm{n}=12)$. Thus, more than one population of calcium channels may exist, and they would be expressed in different proportions, depending on the degree of mRNA purification.

Dose-response for FTX blockade of presynaptic $I_{(\mathrm{Ca})}$ in the squid giant synapse. R. Llinas, M. SUGIMORI, J-W. Lin, AND B. CHERKSEY (Dept. Physiology and Biophysics, NYU Medical Center, New York, NY 10016).

The dose-response relationship for the blocking action of FTX (a toxin fraction from Agalenopsis aperta venom, Sugimori et al. 1988 Biol. Bull. 175: 308; Cherksey et al. 1988, Biol. Bull. 175: 304, Llinas et al. 1989, PNAS, 86: 1689) on the voltage-dependent presynaptic calcium current $\left(\mathrm{I}_{\mathrm{Ca}}\right)$ in the squid stellate ganglion, was determined from voltage clamp measurements. In addition to the purified toxin, we tested the raw venom, and a synthetic poly-amine with an arginine at one end, constructed on the basis of chemical analysis of the FTX fraction (Cherksey et al. 1989, these Abstracts). These substances were added to the bathing solution in concentrations ranging from 0.2 to $190 \mathrm{nl} / \mathrm{ml}$ (volume of venom or liquid synthetic toxin in $\mathrm{nl} / \mathrm{ml}$ seawater). Each of the three fractions had an $\mathrm{ED}_{50}$ of $5 \mathrm{nl} / \mathrm{ml}$ and produced a total blockade at $80-100 \mathrm{nl} / \mathrm{ml}$. The block caused by $100 \mathrm{nl} / \mathrm{ml}$ had a time course of about $20 \mathrm{~min}$ and was very slowly reversible. Comparing the degree of calcium current block with the reduction of the post-synaptic potential, we concluded that the effect of the toxin on synaptic release is totally ascribable to its calcium blocking effect. We reached a similar conclusion about the synthetic polyamine. But because the same volume of raw venom and the synthetic polyamine produced about the same degree of block, we conclude that the active toxin may be more potent, and that the structure of the naturally occurring polyamine is therefore probably a variant of the synthetic product. Finally, we tested some polyamines with an arginine at each terminal of the chain, but $\mathrm{I}_{\mathrm{Ca}}$ was not blocked. Thus, the polyamine may require the terminal amine to penetrate the channel and produce the block; the arginine group may hold the molecule in place.

\section{Modulation of the spontaneous and evoked responses of} lagenar afferents in the toadfish Opsanus tau, by electric pulse stimulation of the efferent vestibular nuclei. Rachel Locke and Stephen M. Highstein (Marine Biological Laboratory, Woods Hole, MA).

The lagena is one of eight acoustico-lateralis mechanoreceptors innervated by the efferent vestibular nuclei (EVN). The ultrastructural morphology of efferent-afferent interactions consists of an efferent terminal on innervated hair cells and a second terminal on innervated afferents. Firing patterns of lagenar afferents encode aspects of head movement, head position, or substrate-borne vibration. Animals were lightly anesthetized with Finquel, MS222 (Ayerst), partially paralyzed by an intramuscular injection of $0.05 \mathrm{mg} / \mathrm{kg}$ of pancuronium bromide, Pavulon (Organon), placed in a lucite experimental tank atop a servocontrolled rotary table and perfused through the mouth with recirculated seawater at $15^{\circ} \mathrm{C}$. Stationary animals were subjected to periods of recording of afferent activity or were oscillated with sinusoidal stimuli in the yaw plane before during and after epochs of electric pulse stimulation $(100 \mathrm{~Hz}, 0.1$-ms wide pulses, $<100 \mu \mathrm{A}$ amplitude constant current) via paired silver wire electrodes inserted visually into the EVN. Afferents range up to $16 \mu \mathrm{m}$ in diameter and can be visually identified and penetrated with glass microelectrodes near the lagenar macula. Recordings reveal spontaneous excitatory post-synaptic potentials (EPSPs) and action potentials (APs). Electrical stimulation of the EVN could either increase or decrease the spontaneous or mechanically evoked firing rates of afferents (number or frequency of APs) depending upon the particular afferent studied. Effects of stimulation were generally stationary; i.e., inhibition could never be converted into excitation by any experimental manipulation, and vice versa. Single, double, triple, etc. pulse stimulation of the EVN evoked monosynaptic EPSPS and APs in afferents whose spontaneous and evoked rate of APs were increased by trains of stimuli. Spontaneous miniature EPSPs from transmitter released by hair cells (EPSPs persisted when EVN axons were severed) had their amplitude and time-to-peak reduced during EVN stimulation. This reduction of "synaptic noise" from hair cells is correlated with a reduction of spontaneous and evoked firing rates. Therefore, we suggest that the EVNs exert a dual control over lagenar primary afferents via the dual innervation of lagenar receptors. We propose that actions of the axo-axonic synapses are responsible for increased firing rates while the axo-somatic synapses on hair cells may be responsible for reducing spontaneous and evoked firing rates.

\section{The effects of GABA on retinal horizontal cells: evidence for an electrogenic uptake mechanism. ROBERT PAUL MALCHOW (Department of Ophthalmology, Univer- sity of Illinois College of Medicine, Chicago, Illinois 60612).}

The inhibitory effects of GABA on neurons are thought to be terminated by uptake into neurons and glia surrounding the release site. Certain classes of retinal horizontal cells avidly accumulate exogenously applied GABA. The present series of experiments were designed to determine if an electrophysiological correlate of the process of GABA uptake could be observed in such cells.

Isolated cells from the retina of the skate (Raja erinacea and Raja ocellata) were obtained by enzymatic dissociation. Voltages and currents from external horizontal cells were recorded using the whole-cell version of the patch-clamp technique. GABA $(500 \mu M)$ applied via pressure ejection from pipettes placed $10-20 \mu \mathrm{m}$ from the cell somas elicited pronounced depolarizations of the cells. When cells were voltage clamped at $-70 \mathrm{mV}$, GABA produced a slow inward current of between $200-500 \mathrm{pA}$ in magnitude; similar applications of $500 \mu \mathrm{M}$ muscimol or $1 \mathrm{~m} M(-)$ baclofen were without effect. The response to GABA was not blocked by superfusion with either $500 \mu M$ bicuculline or $500 \mu \mathrm{M}$ pictrotoxin. However, the response was rapidly and reversibly eliminated by superfusion with sodium-free Ringer. The I-V relationship of the GABA response was similar to that observed for glutamate uptake into glial cells (Brew and Attwell 1987, Nature 327): the current decreased as cells were progressively depolarized, but did not reverse even with cells held at $+70 \mathrm{mV}$.

These data indicate that the effects of GABA on horizontal cells are not due to the activation of either $\mathrm{GABA}_{\mathrm{a}}$ or $\mathrm{GABA}_{\mathrm{b}}$ receptors, but rather reflect electrogenic uptake of GABA into these cells. Skate retinal horizontal cells may prove to be an excellent model system with which to study the process of GABA uptake into neurons.

The author acknowledges the generous support for this research provided by a fellowship from the Grass Foundation.

Electric organ discharge and electrosensory reafference in the little skate, Raja erinacea. JoHN G. NEw (Dept. 
of Neurosciences, A-001, School of Medicine, UCSD, La Jolla, CA 92093).

The electric organs (EO) of the little skate are located laterally along the longitudinal axis of the tail. They are innervated by a series of spinal nerves that receive descending input from the electric organ command nucleus (EOCN) situated on the midline of the rostral medulla (Szabo 1955, J. Physiol 47: 382-385). The weak and irregular discharge of the EOs consists of a head-negative, tail-positive waveform of $10-50 \mathrm{mV}$ amplitude and approximately $70 \mathrm{~ms}$ duration (see Bass 1986, in Electroreception, Bullock and Heiligenberg, eds., J. Wiley, for review). The purpose of this study was to determine the effect of electric organ discharge (EOD) upon the activity of the animal's own electrosensory system.

In alert decerebrated skates, stimulation of the EOCN with a brief, high-frequency train of pulses, results in synchronous discharge of the electric organs. This evoked EOD is indistinguishable from those evoked by tactile or electric field stimuli, or the animal's spontaneous activity.

Recordings from anterior lateral line nerve (ALLN) fibers innervating the electrosensory ampullae of Lorenzini demonstrate different responses to the EOD depending upon the orientation of the receptor and the position of the ampullary pore on the body surface. ALLN fibers, with receptive fields in the caudal third of the pectoral fins, are strongly excited by the EOD (mean max. freq. $=90$ spikes/s), whereas more rostral ampullae are driven more weakly or not at all. Those fibers innervating rostral ampullae and exhibiting modulation are differentially excited or inhibited depending upon ampullary orientation. Analysis of the internal and external electric fields indicates that the EOD acts similarly to an externally applied dipole, producing differential modulation of ALLN activity. This contrasts with the common-phase modulation produced by ventilatory activity.

Supported by a fellowship from the Grass Foundation and NIH NRSA NS-08114.

\section{Stilbene derivatives or chloride replacement by imperme-} ant anions dramatically alter a late component of the light scattering change in mammalian nerve terminals. A. L. Obaid, K. Staley, J. B. Shammash, and B. M. SAlzBerG. (University of Pennsylvania School of Medicine).

Electrical stimulation produces large and rapid changes in the intrinsic optical properties of the neurosecretory terminals of mammalian neurohypophyses. These signals, measured as changes in opacity, reflect alterations in large-angle light scattering, and comprised at least three components. The first of these, the E-wave, coincides with the arrival of excitation in the terminals; the second, the S-wave, is intimately related to the secretion of arginine vasopressin and oxytocin, and the third and slowest component exhibits a complex $\mathrm{N}$-shaped waveform that requires seconds to return to baseline. This slow change in the transparency of the tissue suggested that volume compensation associated with chloride movement might be implicated in determining the time course of the optical signal. Chloride replacement $(90 \%)$ by impermeant anions such as gluconate, isethionate, methyl-sulfate, and methane-sulfonate ( $\mathrm{Ca}$ activity matched to that of the control Ringer's solution) resulted in the reversible loss of the $\mathrm{N}$-shaped waveform and a faster return to baseline with overshoot. The same effect was obtained, although irreversibly, upon the addition of either $0.2-0.5 \mathrm{mM}$ 4-acetamido-4-isothiocyano-stilbene-2,2'-disulfonic acid, disodium salt (SITS-Sigma) or 0.1-0.5 mM 4,4'-dinitrostilbene-2,2'-disulfonic acid, disodium salt (DNDS-Molecular Probes). This result suggests that the late component of the light scattering signal from the nerve terminals of the mouse neurohypophysis is prolonged by transmembrane chloride movements which may be coupled to volume changes in this tissue.

We thank Drs. Wu Jian-Young, Harvey Fishman, and M. V. L. Bennett. Supported by USPHS grant NS 16824 and by fellowships from the Nuffield Foundation (K.S.) and the Short Term Experience in Research Program of the NIH (J.B.S.).

\section{Imaging learning-specific changes in the distribution of protein kinase C. JAMES L. OLDS, DONNA L. MCPHIE, AND DANIEL L. ALKON (NINDS-NIH, Bethesda, MD 20892).}

Protein kinase C (PKC) is an important second messenger in a wide variety of physiological systems. Ongoing work in this laboratory has demonstrated a statistically significant learning-specific change in the distribution of PKC in the rabbit hippocampus.

Rabbits were classically conditioned in the nictating membrane paradigm, and sacrificed either $24 \mathrm{~h}$ or 3 days later. Brains were prepared for quantitative autoradiography by standard methods [Olds et al. 1989, Science (in press)]. Cryosections $(20 \mu \mathrm{m})$ were incubated with $\left[{ }^{3} \mathrm{H}\right]$ phorbol-12,13-dibutyrate (PDBU) at $2.5 \mathrm{n} M$ for $60 \mathrm{~min}$. Non-specific binding was consistently less than $9 \%$ in all assays. We analyzed film autoradiograms of rabbit brain sections and radioactive standards using with a computerized image analysis system.

Conditioned (Group C) animals showed a $49 \%$ and $43 \%$ increase, respectively, in ${ }^{3} \mathrm{H}$-PDBU binding $(P<0.01$, one way ANOVA) in the $\mathrm{CA} 1$ region of the dorsal hippocampus when compared with either unpaired control animals (Group UP), or naives (Group N), 24 h after conditioning. No significant difference was observed between Groups UP and N. Higher resolution transept-line analysis established that the stratum pyrimidale to stratum oriens ratio (SP/SO) was significantly increased over controls, thus showing not only a change in the amount of the enzyme, but also a change in its distribution. An analogous, statistically significant decrease in SP/SO was seen in group 3-C animals, which were sacrificed 3 days after the end of behavioral training. These results suggest that, after an initial increase in soma-localized PKC ( 24 $\mathrm{h}$ after conditioning), the enzyme migrates to areas corresponding to the dendritic compartments of CA 1 pyramidal cells ( 3 days after conditioning). This conditioning-specific change represents a modification in the pattern of PKC distribution that is dependent on behavioral retention time.

\section{A search for correlations in the spike activity of the Aplysia abdominal ganglion during the gill withdrawal reflex. D. SCHIMinOvich, L. B. COHEN, A. I. COHEN, H.-P. HopP, C. X. FALK, AND J.-Y. WU (Department of Physiology, Yale School of Medicine).}

We previously made optical recordings of action potential activity in the Aplysia abdominal ganglion during the gill withdrawal reflex using voltage-sensitive dyes and a 124-element photodiode array. We have now searched for correlations in the spike activity of the optically detected action potentials. High correlation values were given to pairs of cells maintaining exactly the same time difference between some subset of spikes in each cell. The time differences were allowed to deviate by as much as $20 \mathrm{~ms}$, although such deviations would reduce the value we assigned to the correlation. Correlations found at times of high spike activity (just after the touch to the siphon) were given lower values because of an increased probability that the correlations were due to chance. 
Several trials of spike data from seven preparations were searched for correlations. No large correlations were found. To judge whether the small correlations we found were real, we looked for correlations in a file called "random." This file was obtained by taking the experimental spike file and randomly reassigning the time position of each spike in each cell in a region of $250 \mathrm{~ms}$. In this way, the overall appearance of the experimental and random files were similar, while any correlations found in the experimental file should be weakened. However, the correlations found in these random files were just as large as those in the experimental file; we concluded that the correlations in the experimental file were due to chance.

We have considered two kinds of explanations for the absence of correlations. First, the optical recordings were only $20 \%$ to $40 \%$ complete, and we might have observed a special subset of cells (e.g., motor neurons) that were not correlated. On the other hand, the nervous system of the Aplysia may not use many large fast interactions but, instead, either small fast interactions that require the activity of many pre-synaptic cells or slow interactions that would not generate precise intervals between pre- and post-synaptic spikes.

Supported by NIH grant N508437.

\section{On-line rapid determination of $[\mathrm{Ca}] \mathrm{i}$ by means of Fura-} II and high speed video imaging. M. SUGIMORI AND R. LlinÁs (Dept. Physiology and Biophysics, NYU Medical Center, New York, NY 10016).

Calcium concentration changes in the soma and dendrites of mammalian Purkinje cells during spike activity have been determined with the calcium-sensitive dyes Arsenazo III (Ross and Werman 1986, J. Physiol. 389: 319) and more recently Fura-II (Tank et al. 1988, Science 242: 633). In the latter study, a distinction was made between calcium entry, which occurs at the onset of plateau potentials in the peripheral dendritic branchlets, and that which occurs in the main dendritic arbor. The study suggested that the spontaneous activation of Purkinje cells is initiated by an inward calcium current at peripheral dendrites which, upon reaching sufficient amplitude, evoked calcium-dependent action potentials in the main dendritic tree. The measurements reported in that study were obtained at a maximum speed of $250 \mathrm{~ms}$. With improved high speed imaging techniques (a photon counting camera and a high speed video recording system capable of recording $2.5 \mathrm{~ms}$ per frame), we have recorded the actual time course and distribution of calcium entry during single action potentials in Purkinje cells. Because the fluorescence measurements using Fura-II were made at only one light frequency $(380 \mathrm{~nm})$, the measurements indicate only relative calcium concentration changes in the cell cytosol. Simultaneous recordings of light absorption by Fura-II, and of intracellular voltage, clearly indicate that the plateau potentials preceding the activation of Purkinje cells occur in the spiny branchlets. The full action potential is then observed in the main dendrites and is followed by a synchronous, antidromic invasion into the fine dendritic tree. Averaging the calcium signal obtained immediately after the onset of a dendritic spike, and comparing it to that prior to this spike, demonstrates a large calcium influx at the main dendritic field during the spike. Moreover such signals indicate that calcium concentration transients may last for periods of 10 to $15 \mathrm{~ms}$ after which the calcium is buffered or pumped from the cytosol. Thus, $[\mathrm{Ca}] \mathrm{i}$ is very actively modulated. This technique also allows visualization of the Fura-II response to the calcium entry in the presynaptic terminal of the squid giant synapse following a single stimulation to the presynaptic fiber.

Activation of the octavolateralis efferent system in the lateral line of free-swimming toadfish. T. C. TRICAS AND S. M. HighSTEIN (Washington University School of
Medicine, Department of Otolaryngology, St. Louis, MO 63110).

The octavolateralis efferent system (OES) can be activated by multimodal sensory stimuli (Highstein and Baker 1985, J. Neurophysiol. 54: 370 ) and has a predominantly inhibitory action on the firing of lateral line (LL) primary afferent fibers. We studied the OES in a semi-natural setting to determine if visual stimuli could activate it. Single LL afferents were recorded chronically with metal microelectrodes, for periods up to 9 days, in toadfish swimming freely in a small tank monitored by a video system. Primary afferents are grouped into four classes based upon their spontaneous interspike intervals: regular, irregular, bursting, and silent. Silent fibers were mechanically activated by mild $25-$ $90 \mathrm{~Hz}$ vibrations of the experimental tank. Trains of bright photic stimuli (10-100 flashes/s for $1-5 \mathrm{~s}$ ) increased spontaneous spike rates of irregular and bursting afferents, but decreased mechanically evoked afferent firing rates of silent fibers. To test a biologically relevant visual stimulus, a small prey fish was presented in a clear sealed chamber that eliminated all other sensory cues. After presentation of the prey from behind a movable blind, the spontaneous activity of some LL fibers decreased; mechanically evoked firing in silent fibers also decreased for the duration of the stimulus (up to $120 \mathrm{~s}$ ) and recovered to pre-stimulus rates when the blind was closed. Thus, the OES can modulate the activity of LL afferents via visual input pathways in biologically relevant contexts.

\section{Chaotic properties of quantal transmission at the skate neuro-electrocyte junction. J. VAUTRIN, J. HolzaP- PLE, AND M. KRIEBEL (SUNY Health Science Center, Syracuse, NY 13210).}

Spontaneous synaptic activity at neuro-electrocyte junctions has been recorded using focal and intracellular recording techniques. After electrocyte dissociation with collagenase, nerve terminals remain in physiological contact with the electrocytes (see Dowdall et al., these Abstracts). Focally recorded miniature end-plate potentials (MEPPs) from dissociated electrocytes show broad amplitude and time-to-peak distributions that are skewed towards low values. Intervals and time-topeak plots reveal interactions between spontaneous MEPPs. Successive MEPPs often show congruent rising phases, and arise in very bursty patterns. Breaks on MEPP rising phases and changes in slope indicate a sub-structure. Many treatments increase the skew-to-bell-MEPP ratio in frog or mammalian preparations (skew class includes slow- and giant-MEPPs). Temperature changes have a reversible effect on the slope of the skate slow-MEPP. Electrocytes from intact electric organs show periods of MEPPs with the same, fast time course producing bellshaped amplitude distributions with a subunit substructure. These periods of bell-MEPPs alternate with periods of mainly skew-MEPPs. The rapid shifts (seconds) between the two regimes of the spontaneous release process strongly suggest that each MEPP is not due to a performed packet of transmitter, but results from a deterministic process that dynamically combines subunits in different numbers and rates. A simple model, combining subminiature end-plate currents in different numbers and rates, is able to simulate all the observed MEPP amplitudes and time courses. Chaos theory shows that simple systems lead to complicated patterns. We demonstrated that a leaking faucet shows transitions, from a very organized regime with drops of regular size, to instable regimes of various drop sizes that are organized in bursts. Records of drops showing classes of volumes and interval structure are remarkably similar to those of MEPPs.

Supported by NSF 19694 and Association Française contre les Myopathies. 


\section{Pathobiology and Environmental Studies}

\section{Shell disease syndrome in Cancer crabs. ROSEMARIE}

BORKOWSKI AND ROBERT A. BULLIS (University of Pennsylvania, Laboratory for Marine Animal Health, Marine Biological Laboratory).

Gross examinations and microbiological investigations were performed on 14 Cancer borealis (Jonah crab) individuals and 13 Cancer irroratus specimens (rock crab) afflicted with shell disease syndrome. The crabs were collected from near-shore waters between the Chesapeake Bay and Martha's Vineyard. Manifestations of disease varied between and within the two species, indicating a potential for more than one pathogenic process.

Lesions in $C$. borealis: focal blackening without ulceration was the most common dorsal carapace abnormality. Mildly affected animals exhibited punctiform blackening of the dorsal shell, whereas coalescence of numerous black foci throughout at least two-thirds of this region was characteristic of extensive disease. Distribution of all such lesions ranged from markedly symmetrical to decidedly asymmetrical. Lesions of the ventral carapace and appendages included punctiform erosions and small foci of blackening with, or without, central pinpoint ulceration.

Lesions in C. irroratus: the most frequent dorsal carapace abnormality was focal ulceration through the exoskeleton to underlying soft tissues. Shell adjacent to such lesions was blackened and the underlying endocuticle discolored. This ulcerative abnormality occurred at random sites and affected less than one-third of the dorsal shell with the remaining dorsal carapace being normal. Circular erosions arranged in a linear fashion and cracking of the exoskeleton were the primary lesions of the ventral carapace and appendages. Eight of 13 crabs had lost entire appendages or dactylopodites.

Blackening of the gills was noted in both species, as was accumulation of black sediment between the gill bases and exoskeleton.

In $C$. borealis and $C$. irroratus, Vibrio spp. were the most frequent bacterial isolates from normal and affected areas of the exoskeleton; Pseudomonas spp. ranked second in number of isolates. These findings confirm earlier work regarding the genera of bacteria associated with shell disease syndrome.

This study is supported in part by grants from the Division of Research Resources, National Institutes of Health (P40-RR1333-09); Northeast Fisheries Center, National Marine Fisheries Service; and the Madison Trust.

\section{Shell disease in impounded American lobsters, Homarus americanus. ROBERT A. BULlis (University of Penn- sylvania, Laboratory for Marine Animal Health, Ma- rine Biological Laboratory).}

Lobsters held in impoundments during the winter months for long periods can show dramatic increases in shell disease. This unsightly condition affects marketability and can spread rapidly through a population leading to wholesale losses and decreased profitability.

Twenty-five lobsters were sampled from an impoundment in Gran Manan Island, Nova Scotia, during a disease outbreak. Gross examination revealed diffuse pitting erosions covering the entire exoskeleton, but most prominently on the carapace and dorsal abdominal segments. Lesions of the ventral surface were characterized by foci of hyperpigmentation associated with abrasions and scratches. Crushing injuries were manifested by cracking of the exoskeleton and severe blackening of underlying tissues. Lesions of this type are thought to be associated with trauma induced by overcrowding and poor handling.
Microbiological examinations revealed that most individuals had concurrent bacterial septicemia. Microbial isolates from the hemolymph, internal organs, and exoskeleton included chitinolytic, lipolytic, or both types of bacteria from the genera Acinetobacter, Flavobacter, and Pseudomonas. All three genera have previously been implicated in shell disease outbreaks. Physiological and biochemical disturbances in chitin synthesis, and a resulting breakdown in exoskeletal repair, were hypothesized to be the result of stress-induced immunosuppression.

The progression of the disease was altered by placing lobsters in flowthrough containment with three feedings per week of fresh squid and weekly removal of excreta. After six months, lesion severity decreased in moderately affected lobsters.

This work indicates that, although control of ubiquitous chitinolytic bacteria in captive populations is difficult, disease problems may be alleviated by increased attention to hygiene (removal of excreta and selective culling), proper husbandry (adequate nutrition and a clean water supply), and wound avoidance (minimized overcrowding).

This study was supported, in part, by a grant from the Division of Research Resources, National Institutes of Health (P40-RR1333-09) and the generosity of Paul's Lobster Co., Boston, MA.

\section{Marketing, ecological, and policy considerations related to the New England conch fishery and Hoploplana. Ilene M. Kaplan, Barbara C. BOYER, AND DA- NIELA HOFFMANN (Union College).}

Marketing procedures and ecological factors associated with the New England conch (Busycon) fishery, and related changes in Hoploplana, a turbellarian flatworm commensal in the mantle cavity of Busycon, are examined. Conch and pot fishermen were observed at sea on a regular basis, and interviews with fishermen, seafood buyers, processors, and fish market and restaurant owners were conducted. Data on size, width, weight, sex, and number of worms in the conch also were collected.

Conch fishermen are paid $\$ .25-\$ .55$ a pound for conch in the shell; markets sell conch for $\$ .59-\$ 1.19$ per pound in the shell, and $\$ 2.75$ $\$ 3.25$ per pound outside the shell; and conch is sold as conch salad for $\$ 4.99-\$ 6.99$ per pound. The record of annual fluctuations over the past 20 years reveals an overall increase in the pounds of conch meat harvested in New England, as well as an increase in the market value. Conch supply has become more available due to increased fishing, and price fluctuations in the last few years have become less dramatic. Increased fishing for conch has also resulted in heightened competition between pot fishermen using traditional techniques and larger stern trawlers.

A total of 741 specimens of Busycon canaliculatum were examined (466 females and 264 males). Approximately $20 \%$ yielded 223 worms, 154 from females and 69 from males.

Further monitoring of the conch fishery is suggested for future research and policy considerations.

This research was supported by a grant from Earthwatch and Union College/Dana Fellowships. The authors also acknowledge the support of the Marine Policy Center, Woods Hole Oceanographic Institution, and the Marine Biological Laboratory.

\section{The sperm cell's silent spring: herbicides and pesticides. LEONARD NeLson (Medical College of Ohio, Toledo, $\mathrm{OH} 43699$ ).}

In 1962, Rachel Carson alerted the world to the fact that the indiscriminate use of DDT and other chlorinated hydrocarbons led to reproductive failure and to the death of birds and other animals. Spermato- 
zoa are also adversely affected by these pesticides, organophosphates, and organometallic compounds. Water-insoluble agents dissolve in DMSO (dimethyl sulfoxide); and because of their lipophilicity, they readily penetrate plasma membrane lipoproteins. The high surface-tovolume ratio of flagella makes sperm cells particularly vulnerable. $\mathrm{Ar}$ bacia punctulata cells suspended in artificial seawater respond doseand time-dependently.

Paraoxon, an anticholinesterase insecticide, reversibly stimulates motile progression after $5 \mathrm{~min}(0.7-70 \mu M)$. Dieldrin and lindane are chlorinated hydrocarbons that can stimulate the vertebrate central nervous system to convulsions. These compounds are effective in the micromolar range: above 30 to $100 \mu M$ dieldrin inhibits; between 1 and 15 it stimulates initially; and lindane mainly depresses $(0.4-13 \mu M)$. Mirex, an inducer of the cytochrome P-450 system, is a persistent insecticide and fire-retardant (carcinogen). This compound markedly stimulates sperm $(0.2-1 \mu M)$, but initially depresses them at lower ranges.

The organometallic ethyl mercuric chloride is a fungicide used to treat seeds. It inhibits sperm movement $(1-5 \mu M)$, but slightly increases it ( $50-55 \mathrm{n} M)$, apparently by deregulating sulfhydryl control systems. Tributyltin acetate, used in boat bottom paint to reduce fouling, decreases sperm movement between 0.065 and $65 \mathrm{n} M$.

These organic pesticides and their inorganic counterparts affect the function of sperm cells, which can serve as sensitive indices of toxicants in the environment.

Supported by the Sage Foundation.

\section{Sensory Biology}

\section{Subnose 1: tracking oceanic odor plumes with high spa-} tiotemporal resolution. Jelle Atema, Greg GerHaRdT, Paul Moore, and Laurence Madin (Boston University Marine Program, Marine Biological Laboratory, Woods Hole, MA 02543).

In May 1989, we employed electrochemical microelectrode techniques to measure the fine structure of an oceanic odor plume at 1000 $\mathrm{m}$ depth off St. Croix, USVI. To avoid interference from unknown chemical compounds, we used a dopamine tracer and a selective dopamine detection method used previously to measure dopamine diffusion in brain tissue.

"Subnose" is an underwater detector that can sample specific chemical compounds with the spatiotemporal resolution of biological noses or better. The detector was mounted on a $1.5-\mathrm{m}$ long stick that could be operated by the mechanical arm of the Johnson-Sealink submersible. For "Subnose-1" we averaged the signals from three graphite-epoxy type microelectrodes, each with a sampling surface of about $30 \mu \mathrm{m}$ diameter. An odor plume was made by releasing a $50 \mathrm{mM}$ solution of dopamine, together with fluoresceine dye, from a moored platform about $15 \mathrm{~m}$ above the sea floor. The solution was released evenly through a small nozzle ( $3 \mathrm{~mm}$ diameter) from a $10-1$ reservoir over a 45-min period. Ambient turbulence created a characteristically patchy plume carried down by a $10 \mathrm{~cm} / \mathrm{s}$ current. The plume was located visually and tracked for $25 \mathrm{~min}$ with Subnose-1, from about $50 \mathrm{~m}$ downcurrent, up to about $5 \mathrm{~m}$ from the source. The patchy distribution of visible dye was represented as a series of sharp peaks when patches of dopamine were encountered by the electrodes. Several peak parameters were measured based on peak definitions given in Moore and Atema (1988, Biol. Bull. 174: 355). Peak heights and maximum onset slopes rose toward the source indicating steeper and higher peaks near the release point. Patch sizes (area) decreased toward the source. Other parameters did not show spatial gradients. Although the present, visually guided track is a rather arbitrary series of encounters with odor, peak parameters such as peak height and slope could be used by aquatic ani- mals to orient and locate odor sources regardless of an external frame of reference (e.g., seafloor). This information may be critical for midwater animals, and useful for benthic animals, in their orientation.

\section{Response of bluefish (Pomatomus saltatrix) to increased intracranial pressure (Cushing response). STEPHEN $\mathrm{H}$. Fox, Christopher S. Ogilvy, and Arthur B. Du- Bols (The John B. Pierce Foundation Laboratory, New Haven, CT 06519).}

Bluefish have vasomotor responses to hemorrhage, or to head-up tilting in air (Ogilvy et al. 1989, Biol. Bull. 176: 176-190). Increases of intracranial pressure (ICP) induce increases of blood pressure (BP) in mammals (Cushing response). We increased ICP via metal implants in the skull and observed heart rate (HR) and BP in the ventral aorta. BP and HR increased in all 21 fish challenged, whether or not the fish were anesthetized with tricaine ( $1 \mathrm{~g} / 401$ seawater) or were rendered flaccid with pancuronium $(0.1 \mathrm{mg} / \mathrm{kg})$. Mean BP increased from 83 (SE 4) to 126 (SE 4$) \mathrm{mm} \mathrm{Hg}$, and $\mathrm{HR}$ from $46 \pm 4$ to $75 \pm 2$ beats per min (BPM), as ICP was increased in $10 \mathrm{~mm} \mathrm{Hg}$ steps of 20 s duration, from $3 \pm 1$ to $65 \pm 1 \mathrm{~mm} \mathrm{Hg}$, in five bluefish. In five other bluefish, atropine (20 $\mu \mathrm{g} / \mathrm{kg}$ ) caused an increase in control heart rate and attenuated the increase of HR and BP during increases in ICP. In five more, phentolamine $(400 \mu \mathrm{g} / \mathrm{kg})$ lowered the resting BP and blunted the increase of $\mathrm{BP}$ during increased ICP. Atropine and phentolamine in combination completely eliminated the Cushing response in two fish (and the response to intraarterial epinephrine $(4 \mu \mathrm{g} / \mathrm{kg})$ in one of these); but in three other bluefish, the Cushing response was reduced yet not eliminated, and in two of these, epinephrine response was not blocked. The Cushing response starts in 3-5 s, stops 3-5 s after ICP drops, and can persist at least $30 \mathrm{~min}$ if ICP remains elevated at $16 \mathrm{~mm} \mathrm{Hg}$. The response was repeatable after recovery from atropine and phentolamine. The Cushing response was elicited by pressure exerted on the eyeballs, which raises ICP, or by an increase of air pressure over the exposed brain. Based on these experiments, the BP response in bluefish is mediated through tachycardia and vasoconstriction. The role of this response in fish in their natural environment remains to be elucidated.

\section{A novel chemosensory system in fish: do rocklings (Cili- ata mustela, Gadidae) use their solitary chemoreceptor cells as fish detectors? KURT KOTRSCHAL (University of Salzburg, Austria), RoB Peters, AND Jelle ATEMA.}

Solitary chemoreceptor cells (SCC) of unknown function and biological role are scattered throughout the epidermis of most fish. Rocklings are favorable models for SCC research, as their modified anterior dorsal fin (ADF) contains several million SCC, but no taste buds (Kotrschal et al. 1984, Zoomorphology 104: 365-372). These secondary sensory cells make synapses exclusively with recurrent facial nerve fibers (Whitear and Kotrschal 1988, J. Zool. Lond 216: 339-366), which terminate in a distinct subdivision of the brainstem facial lobe (Kotrschal and Whitear 1988, J. Comp. Neurol. 268: 109-120). Body mucus dilutions of heterospecifics elicited responses in summed potential recordings (Peters et al. 1987, J. Mar. Biol. Assoc. U.K. 67: 819-823; these abstracts).

To test the hypothesis that the ADF is a "fish detector," the breathing frequency (BTF) of four groups of rocklings (sham, closed noses, ADF removed, closed noses plus ADF removed) was recorded prior to, and during, a 2-min addition of stimulus to the tank water (Lophius plus Opsanus mucus solution $0.1 \%$ stock, or squid extract, or mucus water and squid extract simultaneously, six replicates per fish, four fish per treatment). Sham fish responded to mucus water with a significant drop 
in BTF. In fish with closed noses, this response was weaker, but still significant. From fish with removed ADF, no BTF response to mucus water could be detected, even when the nose was intact. Squid juice did not affect the BTF, whereas squid juice together with body mucus produced a significant drop of BTF in the sham group. We conclude that fish body mucus is a biologically relevant stimulus for the ADF SCC in rocklings. Olfaction seems essential to interpret the ADF input. We predict, and subsequently will test with neuroanatomical techniques, that the brain connections of the ADF system are similar to that of the external taste buds, and the inputs from the ADF and the olfactory organ are integrated at prosencephalic levels.

The authors acknowledge the financial support of the Austrian Fonds zur Foerd. wiss. Forsch., proj. nr. J0367-BIO, the Royal Netherlands Acad. Sci., and the Dutch-Austrian cultural exchange program.

\section{Potential gradient information contained within the three-dimensional structure of a laboratory odor plume. Paul MoOre, Nat Scholz, Lynne La- COMIS, AND Jelle ATEMA (Boston University Marine Program, Marine Biological Laboratory, Woods Hole, MA 02543).}

Odor plumes serve as sources of information for many animals during chemically mediated orientation. The information contained within the odor plume is poorly understood because the spatial and temporal scales at which chemoreceptor cells and organs function have been difficult to match with conventional chemical detectors. With newly introduced electrochemical microelectrodes (Moore et al. 1989, Chem. Senses 13: in press), we can sample certain chemical tracers, such as dopamine, at micrometer space scales and millisecond time scales. In this study, we used this high resolution measurement to sample the three-dimensional structure of an odor plume under controlled laboratory conditions. An odor plume was created in a uni-directional seawater flume $(90 \times 250 \times 20 \mathrm{~cm})$. A $2-\mathrm{m} M$ dopamine tracer flowed $(50 \mathrm{ml} / \mathrm{min})$ through a Pasteur pipette ( $1 \mathrm{~mm}$ ID) located $9 \mathrm{~cm}$ from the bottom in the cross-sectional center of the flume; lobsters sample in a plane about $9 \mathrm{~cm}$ from the bottom. After allowing the plume to establish itself for $2 \mathrm{~min}$, an odor profile was recorded for $3 \mathrm{~min}$ using a graphite-epoxy capillary electrode and a computer-based recording system (IVEC-V). The sample sites were located at 25,50 , and $100 \mathrm{~cm}$ from the pipette mouth; at 3,9 , and $15 \mathrm{~cm}$ from the flume bottom, and at $0,5,10,20$, and $30 \mathrm{~cm}$ to the right and left of the pipette. These recordings were analyzed for odor pulse parameters by procedures developed in Moore and Atema (1988, Biol. Bull. 174: 355-363). Initial three-dimensional analysis of parameters that describe odor pulse shapes and frequencies shows that spatial gradients of certain parameter values point to the source. Specifically, the frequency of large peak heights and large onset slopes increase toward the source, whereas other parameters decrease, and yet others remain constant (see also Atema et al., these Abstracts). Animals may use this gradient information during orientation behavior, and their chemoreceptor filter properties may be "tuned" to certain odor pulse parameters (see abstracts by Scholz et al., and Voigt and Atema).

Supported by NSF (BNS 88-12952) to J.A.

\footnotetext{
A novel chemosensory system in fish: electrophysiological evidence for mucus detection by solitary chemoreceptor cells in rocklings (Ciliata mustela, Gadidae). ROBERT C. Peters (University of Utrecht, The Netherlands), Kurt Kotrschal, Wolf-Dietrich KrautgartNER, AND JELLE ATEMA.
}

Rocklings possess anterior dorsal fins (ADF) that are modified compared to other teleostean dorsal fins. The ADF consists of about 60 vibratile rays with a web only at the base; the first ray is enlarged. The vibratile rays are beset with about $5,000,000$ solitary chemoreceptor cells (SCC). These SCCs are designated as chemoreceptor cells on ultrastructural criteria (Whitear 1971, J. Zool. Lond. 163: 237-264; Kotrschal et al. 1984, Zoomorphology 104: 365-372). Electrophysiological studies demonstrated "tuning" of the SCCs to mucoid stimuli (Peters et al. 1987, J. Mar. Biol. Assoc. U.K. 67: 819-823).

The present experiments were designed to further specify the adequate stimulus and to compare the responses of the SCCs to those of taste buds (TB) in the pectoral and pelvic fins. Rocklings were anaesthetized with MS-222, and silver wire electrodes were then implanted around the recurrent facial nerve innervating the SCCs and around the facial nerves innervating the TBs. Summed potential recordings were made in unrestrained fish. Both groups of sensory organs were stimulated with body mucus of Gadus, Ciliata, Solea, Pholis, Cottus, Mugil, and Zoarces, and with the amino acids L-Arg, L-Ala, L-Cys, L-Gly, and L-Asp (1 mM).

The SCCs reacted to body mucus of all the fish mentioned above, except for that of conspecifics (Ciliata); the SCCs were insensitive to amino acids. The TBs, on the other hand, did not react to body mucus, but gave vigorous responses to amino acids.

These results suggest a specific function for the SCCs. The sensitivity of these receptors to body mucus might represent a chemosensory compensation for the limited vision of the rocklings in their highly structured and tidal habitat. This ability may help them discriminate between conspecifics and predators.

The authors gratefully acknowledge the financial support of the Royal Netherlands Academy of Sciences, the Fonds zur Förderung der Wissenschaftlichen Forschung in Österreich proj. nr. J0367-BIO, and the Austrian-Dutch cultural exchange program.

\section{Chemo-orientation of the lobster, Homarus americanus, to a point source in a laboratory flume. NAT SCHOLZ, Paul Moore, Lynne Lacomis, and Jelle Atema (Boston University Marine Program Marine Biologi- cal Laboratory, Woods Hole, MA 02543).}

Many animals use chemical cues contained within turbulent odor plumes for orientation, but the relevant parameters of the plume are not known. Orientation studies in aquatic environments have advantages over those in terrestrial environments because odor distribution patterns can be more accurately measured, and stimulus delivery more closely controlled. We chose the lobster, Homarus americanus, because of its size and ease of handling, and the extensive base of neurophysiological data on the properties of its chemoreceptors. Previous behavioral studies indicate that the lobster relies heavily on chemosensory input in its natural habitat and specifically on antennular chemoreception for efficient orientation (Devine and Atema 1982, Biol. Bull. 163: 144-153).

In a flow-through flume $(90 \times 250 \times 20 \mathrm{~cm})$, lobsters oriented towards a stimulus $(0.5 \mathrm{~g} / \mathrm{l}$ homogenized and centrifuged mussel tissue in raw seawater) constantly flowing from a pipette two meters upcurrent. The flow parameters were identical to those used for detailed plume description in Moore et al. (these Abstracts). Lobsters were placed on a mussel diet, and then starved for at least three days prior to testing. Tests were videotaped with a camera mounted directly overhead on a moveable track; tapes were digitized at $1 \mathrm{~Hz}$ with the rostrum as the reference point. From casual inspection of the resulting walking paths, we favor the hypothesis of direct chemosensory control of orientation (i.e., "chemotaxis") rather than an innate behavior program (such as zig-zagging) triggered by chemical input. These preliminary results 
have established the lobster as a viable model for studying chemo-orientation and chemical information extraction in turbulent odor plumes.

Supported by NSF (BNS 88-12952) to J.A.

\section{Responses of chemoreceptor cells to controlled temporal stimulus patterns. RAINER VOIGT AND JELLE ATEMA (Boston University Marine Program, Marine Biologi- cal Laboratory, Woods Hole, MA 02543).}

The lateral antennules of the lobster, Homarus americanus, play an important role in olfactory orientation. Taurine- (Tau) sensitive chemoreceptor cells on the antennules form a narrowly tuned and highly sensitive cell population. Tau occurs in high concentrations in lobster prey and in extremely low concentrations in coastal waters; this low natural background may enhance the value of Tau as a long distance orientation cue. Natural odor plumes can be described by stimulus pulse intensity, background concentration, and repetition rate of pulses. To determine the adaptation and dis-adaptation properties of chemoreceptor cells, we tested single chemoreceptors with a series of 10 Tau pulses in different concentrations and different background concentrations, and varied the interstimulus intervals.

Chemoreceptor cells were recorded extracellularly with suction electrodes. Single cells were identified with a standard Tau pulse $\left(7 \times 10^{-5}\right.$ $M)$. A train of 10 pulses in one of four concentrations $\left(7 \times 10^{-4} \mathrm{M}\right.$ to 7 $\times 10^{-7} \mathrm{M}$ ) was applied in a $10^{-7} \mathrm{M}$ Tau background in one of three pulse intervals $(2.5 \mathrm{~s}, 5 \mathrm{~s}, 10 \mathrm{~s})$. Each of these 12 trains was separated by a 3-min recovery period. After $3 \mathrm{~min}$ of recovery in artificial seawater, the series of trains was repeated in $10^{-6} \mathrm{M}, 10^{-5} \mathrm{M}, 10^{-4} \mathrm{M}$, and $10^{-3} \mathrm{M}$ Tau backgrounds.

Individual cells showed a wide range of cummulative adaptation. Stimulus-response functions revealed range fractionation. In general, shorter pulse intervals resulted in gradually stronger cumulative adaptation. Weaker pulse concentrations caused less cumulative adaptation. All but the highest background had negligible effects on response magnitude, showing the efficiency of background adaptation. Cumulative adaptation occurred mostly during the first three stimuli, and mostly with strong pulse concentrations in low background.

Thus, low-firing cells showed good response reproducibility (i.e., no cumulative adaptation) even with the shortest pulse interval, whether low firing rates were caused by internal cell properties, low stimulus concentration, or high background concentration. This state of adaptation may be natural for cells operating in odor plume conditions.

Supported by a grant from NSF (BNS 88-12952) to J.A.
Spectral tuning to amino acids and mixture effects on antennular chemoreceptor cells in the lobster. Homarus americanus. ANNA WEINSTEIN, RAINER Voigt, AND Jelle Atema (Boston University Marine Program, Marine Biological Laboratory, Woods Hole, MA 02543).

Lobster antennules are chemoreceptor organs that play a major role in orientation behavior. Hydroxyproline-best and taurine-best cell populations dominate their amino acid tuning spectrum. We tested the response of chemoreceptor cells on the lateral antennule to 15 amino acids and to 3 mixtures containing these amino acids to determine the effect of search mixture composition on spectral tuning.

The mixtures we used reflect the prominence of hydroxyproline (Hyp) and taurine (Tau) as best compounds for antennular chemoreceptors. All three mixtures had a total concentration of $1.5 \times 10^{-3} \mathrm{M}$. "Equimolar mixture" contained all the compounds in equal concentration $\left(10^{-4} \mathrm{M}\right)$. The other two mixtures were based on the amino acid composition of a lobster prey, Mytilus edulis, modified by adjusting concentrations of Hyp and Tau. "Tau mixture" contained Tau at 3 $\times 10^{-4} \mathrm{M}$ and Hyp at $10^{-4} \mathrm{M}$. "Tau-Hyp mixture" contained both Tau and Hyp at $10^{-4} M$. Thus, all mixtures contained Hyp at $10^{-4} M$. Tau mixture was used as the search mixture. The mixtures and compounds were injected at 1 -min intervals into a carrier flow of artificial seawater which passed over the antennule. Action potentials were recorded with a suction electrode in excised antennules.

Twelve of the 21 cells were narrowly tuned to Hyp: three exclusively to Hyp, and nine with secondary responses mainly to glycine and arginine. Three cells were narrowly tuned to Tau, showing consistently strong responses. Four cells were tuned to glutamate, one to serine, and one to leucine.

For each Hyp-best cell, all three mixtures caused similar responses (Wilcoxon, $P>0.05$ ) that were significantly less than responses to Hyp. Therefore, searching with any one of these mixtures would reveal a similar receptor population. However, cells that are completely suppressed by a search mixture only appear as "by-products" in recordings where more than one cell can be discriminated with extracellular techniques.

The results show that similar tuning spectra are revealed by searching with an equimolar "nonsense" mixture (Johnson and Atema 1983, Neurosci. Lett. 41: 145-150) and natural mixtures of amino acids, all containing the same Hyp concentrations.

Supported by a grant from NSF (BNS 88-12952) to J.A. 


\section{$2 \mathrm{BHL}$ Biodiversity Heritage Library}

1989. "Abstracts of Papers Presented at the General Scientific Meetings of the Marine Biological Laboratory." The Biological bulletin 177, 313-330.

View This Item Online: https://www.biodiversitylibrary.org/item/17220

Permalink: https://www.biodiversitylibrary.org/partpdf/39213

\section{Holding Institution}

MBLWHOI Library

\section{Sponsored by}

MBLWHOI Library

\section{Copyright \& Reuse}

Copyright Status: In copyright. Digitized with the permission of the rights holder.

License: http://creativecommons.org/licenses/by-nc-sa/3.0/

Rights: https://biodiversitylibrary.org/permissions

This document was created from content at the Biodiversity Heritage Library, the world's largest open access digital library for biodiversity literature and archives. Visit BHL at https://www.biodiversitylibrary.org. 